\title{
Nucleic acid-based biosensors: analytical devices for prevention, diagnosis and treatment of diseases
}

\author{
Biosensores basados en ácidos nucleicos: dispositivos \\ analíticos para la prevención, el diagnóstico y tratamiento \\ de enfermedades
}

Laura Carvajal Barbosa ${ }^{1}$, Diego Insuasty Cepeda ${ }^{2}$, Andrés Felipe León Torres ${ }^{3}$, María Mercedes Arias Cortes ${ }^{3(\mathbb{D})}$, Zuly Jenny Rivera Monroy ${ }^{2 \mathbb{1}}$, Javier Eduardo Garcia Castaneda ${ }^{1 *(1)}$.

\begin{abstract}
BACKGROUND: Biosensing techniques have been the subject of exponentially increasing interest due to their performance advantages such as high selectivity and sensitivity, easy operation, low cost, short analysis time, simple sample preparation, and real-time detection. Biosensors have been developed by integrating the unique specificity of biological reactions and the high sensitivity of physical sensors. Therefore, there has been a broad scope of applications for biosensing techniques, and nowadays, they are ubiquitous in different areas of environmental, healthcare, and food safety. Biosensors have been used for environmental

studies, detecting and quantifying pollutants in water, air, and soil. Biosensors also showed great potential for developing analytical tools with countless applications in diagnosing, preventing, and treating diseases, mainly by detecting biomarkers. Biosensors as a medical device can identify nucleic acids, proteins, peptides, metabolites, etc.; these analytes may be biomarkers associated with the disease status. Bacterial food contamination is considered a worldwide public health issue; biosensor-based analytical techniques can identify the presence or absence of pathogenic agents in food. OBJECTIVES: The present review aims to establish state-of-the-art, comprising the recent advances in the use of nucleic acid-based biosensors and their novel application for the detection of nucleic acids. Emphasis will be given to the performance characteristics, advantages, and challenges. Additionally, food safety applications of nucleic acid-based biosensors will be discussed. METHODS: Recent research articles related to nucleic acid-based biosensors, biosensors for detecting nucleic acids, biosensors and food safety, and biosensors in environmental monitoring were reviewed. Also, biosensing platforms associated with the clinical diagnosis and food industry were included. RESULTS: It is possible to appreciate that multiple applications of nucleic acid-based biosensors have been reported in the diagnosis, prevention, and treatment of diseases, as well as to identify foodborne pathogenic bacteria. The use of PNA and aptamers opens the possibility of developing new biometric tools with better analytical properties. CONCLUSIONS: Biosensors could be considered the most important tool for preventing, treating, and monitoring diseases that significantly impact human health. The aptamers have advantages as biorecognition elements due to the structural conformation, hybridization capacity, robustness, stability, and lower costs. It is necessary to implement biosensors in situ to identify analytes with high selectivity and lower detection limits.
\end{abstract}

JOURNAL VITAE

School of Pharmaceutical and Food Sciences

ISSN 0121-4004 | ISSNe 2145-2660

University of Antioquia Medellin, Colombia

Filliations

${ }^{1}$ Pharmacy Department, Sciences Faculty, Universidad Nacional de Colombia, Carrera 45 \# 26 - 85, Edificio 450, Bogotá D.C., Colombia.

${ }^{2}$ Chemistry Department, Sciences Faculty, Universidad Nacional de Colombia, Carrera 45 \# 26 - 85, Edificio 451, Bogotá D.C., Colombia.

${ }^{3}$ Metrology and Bioanalysis Group, Instituto Nacional de Metrología de Colombia, Avenida carrera 50 \# 26-55, Bogotá D.C., Colombia.

*Corresponding Javier Eduardo Garcia Castaneda jaegarciaca@unal.edu.co

Received: 17 August 2021 Accepted: 06 November 2021 Published: 09 December 2021
Key words: Biosensors, Nucleic acid-based biosensors, Bioreceptor, Diagnosis and monitoring of diseases, Biomarkers, Pathogens identification, Food safety. 


\section{RESUMEN}

ANTECEDENTES: Las técnicas de biodetección han sido objeto de un interés cada vez mayor debido a ventajas, tales como alta selectividad y sensibilidad, facilidad de manejo, bajo costo, tiempo de análisis corto, preparación sencilla de muestras y detección en tiempo real. Los biosensores se han desarrollado integrando la especificidad única de las reacciones biológicas y la alta sensibilidad de los sensores físicos. Por lo tanto, las técnicas de biodetección han tenido un amplio campo de aplicación y hoy en día son omnipresentes en diferentes áreas del medio ambiente, la salud y la seguridad alimentaria. Se han utilizado biosensores para estudios ambientales, detectando y cuantificando contaminantes en el agua, el aire y el suelo. Los biosensores también mostraron un gran potencial para desarrollar herramientas analíticas con innumerables aplicaciones en el diagnóstico, prevención y tratamiento de enfermedades, principalmente mediante la detección de biomarcadores. Los biosensores como dispositivo médico pueden utilizarse para identificar ácidos nucleicos, proteínas, péptidos, metabolitos, etc. Estos analitos pueden ser biomarcadores asociados al estado de la enfermedad. La contaminación bacteriana de los alimentos se considera un problema de salud pública mundial; se pueden utilizar técnicas analíticas basadas en biosensores para determinar la presencia o ausencia de agentes patógenos en los alimentos. OBJETIVOS: La presente revisión tiene por objeto establecer los últimos adelantos en la utilización de biosensores basados en ácidos nucleicos y su novedosa aplicación para la detección de ácidos nucleicos. Se hará hincapié en las características del desempeño, las ventajas y los desafíos. Además, se examinarán las aplicaciones de los biosensores basados en ácidos nucleicos para la inocuidad de los alimentos. MÉTODOS: Se examinaron artículos de investigación recientes relacionados con los biosensores a base de ácidos nucleicos, los biosensores para la detección de ácidos nucleicos, los biosensores y la inocuidad de los alimentos, y los biosensores para la vigilancia del medio ambiente. También se incluyeron plataformas de biosensores asociadas al diagnóstico clínico y a la industria alimentaria. RESULTADOS: Es posible apreciar que se han reportado múltiples aplicaciones de biosensores basados en ácido nucleico para el diagnóstico, prevención y tratamiento de enfermedades, así como para identificar bacterias patógenas transmitidas por los alimentos. El uso de PNA y aptámeros abre la posibilidad de desarrollar nuevas herramientas biométricas con mejores propiedades analíticas. CONCLUSIONES: Los biosensores pueden ser considerados como los instrumentos más importantes para la prevención, el tratamiento y la vigilancia de las enfermedades que tienen un impacto significativo en la salud humana. Los aptámeros tienen ventajas como elemento de biorreconocimiento debido a la conformación estructural, capacidad de hibridación, robustez, estabilidad y menores costos. Es necesario implementar biosensores in situ para identificar analitos con alta selectividad y menores límites de detección.

Palabras clave: Biosensores, biosensores basados en ácidos nucleicos, bioreceptores, diagnóstico y monitoreo de enfermedades, biomarcadores, identificación de patógenos, inocuidad alimentaria.

\section{INTRODUCTION}

A biosensor is a unified device that can detect analytes (bacteria, fungi, cancer cells, biomarkers, drugs, peptides, proteins, hormones, pollutants, food, and additives, etc.) found in complex matrices (water, air, soil, biological samples, in vitro systems, etc.)(1). Biosensing techniques have gained exponential interest due to their advantages, such as high selectivity and sensitivity, short analysis cycle, and real-time sensing (2). They have been developed by integrating the unique specificity of biological reactions and the high sensitivity of physical sensors
(2). A biosensor can be defined as an analytical electronic device that generates an electronic signal through receptor-target analyte interactions (3). Its main principle is to detect the molecular recognition event and transform it into a measurable signal in a process called signalization (4-6). As shown in Figure 1 , its basic components include (i) a bioreceptor or biological recognition system capable of detecting the analyte, (ii) a transducer required to convert the biorecognition event into a measurable signal, and (iii) a signal processing system to prepare the signal for display in a user-friendly manner (4-7). 


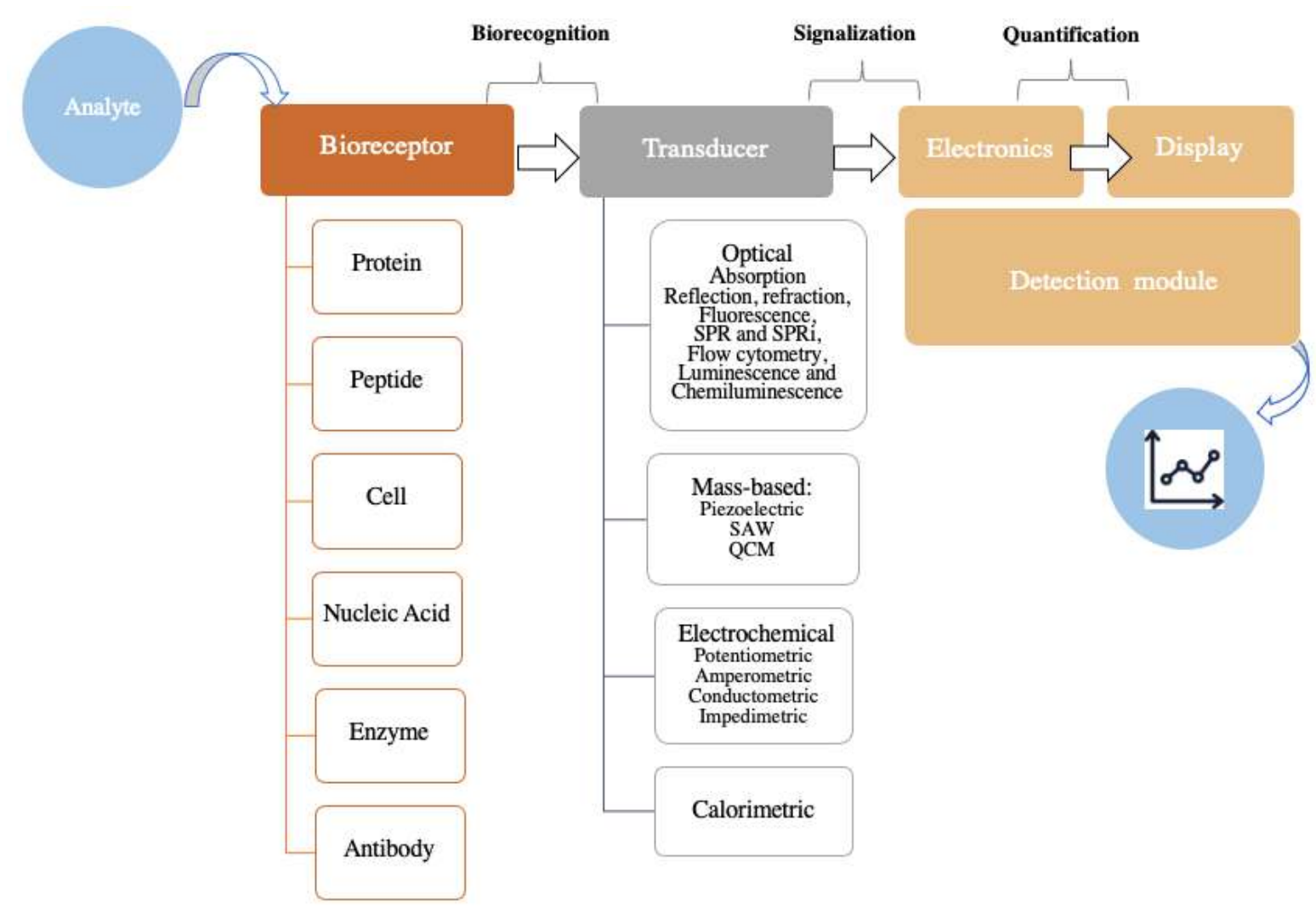

Figure 1. Schematic representation of a biosensor. SPR: surface plasmon resonance; SPRi: surface plasmon resonance imaging; SAW: surface acoustic waves-based; QCM: quartz crystal microbalance. (Adapted from (3-7).

Biosensors can be classified based on the nature of the bioreceptor or transducer employed, as shown in Figure 1. First, in relation to the biomolecules comprising the recognition system, a biosensor can be protein-, peptide-, cell-, nucleic acid-, enzyme-, antibody-, or biomimetic-based. And second, with regards to the type of transducer, a biosensor can be classified as optical (absorption, reflection, refraction, fluorescence, luminescence, etc.), mass-based (piezoelectric), electrochemical (potentiometric, amperometric, impedimetric, etc.), or calorimetric, among other possibilities (3,5-7).

In order to develop a biosensor, several things need to be considered: first, the identification of the target analyte, then the selection of a suitable bioreceptor molecule with the appropriate immobilization method, and last, the determination of a suitable transducer (8). However, as the process continues, it is necessary to quantify and optimize parameters such as the measurement range, linearity, interference, and biosensor packaging (8). An ideal biosensor could be characterized as having high selectivity, sensitivity, reproducibility, accuracy, reliability, robustness, and stability $(8,9)$.
In the field of biosensing techniques, researchers often aim to develop a portable device that can perform rapid detection, be reusable, and have the potential to prevent costly laboratory tests(8). Moreover, biosensors are expected to match the ASSURED criteria established by the World Health Organization (WHO), which stands for Affordable, Sensitive, Specific, User-friendly, Rapid and Robust, Equipment-free, and Deliverable to end-users (10). Recently, portability has gained importance because of its potential applicability to the point of care (11).

Biosensing techniques have broadened their scope of applications and nowadays are ubiquitous in different fields, including clinical disease monitoring, medical devices, and drug delivery systems (Figure 2) (4). The recognition of disease status at the biomolecular level has attracted wide attention from researchers (12). Due to their relation to gene expression, nucleic acids are among the most important biomarkers and are the most frequently investigated among biomolecules $(9,13)$. Even small changes in nucleic acid sequences can lead to notable biological and biomedical implications $(9,13)$. For instance, single nucleotide polymorphisms 
(SNPs) are believed to reveal the genetic basis of individual susceptibility to disease and the diverse responses to treatment (2). Thus nucleic acid-based biosensors are required to incorporate amplification strategies to detect the presence of low-abundant mutations (9).

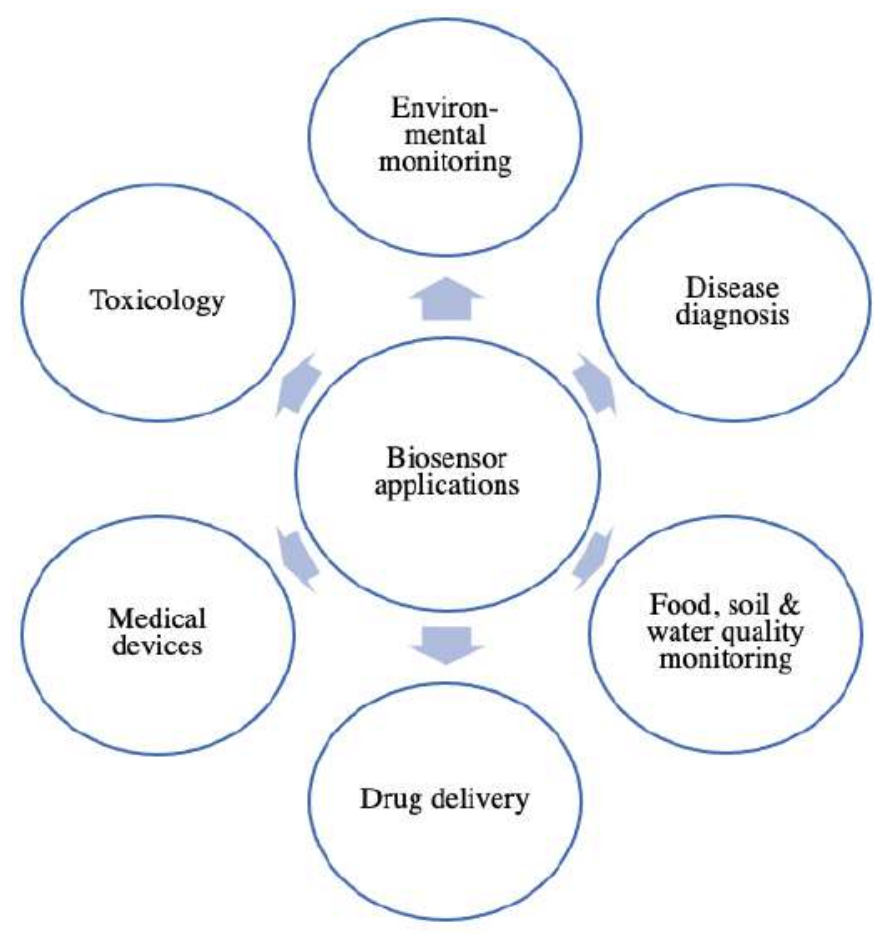

Figure 2. Scope of applications for biosensing techniques. (Adapted from $(4,6)$.)

A nucleic acid-based sensor or genosensor is a biosensor that functionalizes a single strand of nucleic acid as the biorecognition element and immobilizes it on the surface of a transducer (3). The biorecognition event will be detailed in the next section (7). Considering that the sensing elements employed are oligonucleotides, genosensors can detect specific DNA, RNA, or aptamer sequences. The central importance of nucleic acid-based biosensors is associated with detecting disease biomarkers, early disease diagnostics, gene therapy, and pathogen determination (9,13-15). Furthermore, nucleic acid detection is essential in food safety, especially for the monitoring of foodborne disease pathogens and mycotoxins (14). Nucleic acids can be immobilized in the biosensor, working as the biorecognition element, but they can also constitute the target analyte.

A major safety concern for using biosensors for in vitro diagnostics is associated with the risk of misdiagnosis due to a false-positive or falsenegative result. This would lead to inappropriate patient management and even to an inadequate public health response (16). In order to reduce the risk of misdiagnosis, regulatory agencies, such as the United States Food and Drug Administration (FDA), have developed guidelines, standards, operating procedures, and performance criteria applicable to major aspects of biosensor manufacturing and use (16). However, good reproducibility of results in the final prototype could still be a challenge, interfering with the compliance of regulatory aspects (17).

Considering the advantages of biosensing techniques such as easy operation, low cost, and simple sample preparation; their potential development for pointof-care diagnostics in developing countries has been investigated (17). In these countries, where main complex medical infrastructures are unavailable, infectious diseases and antimicrobial resistance cause a large disease burden (17). However, further efforts should be directed towards implementing biosensing techniques as diagnostic tools in developing countries.

This review aims to establish state of art, comprising the recent advances in the use of nucleic acidbased biosensors and their novel applications to the detection of nucleic acids. Particular emphasis will be given to the performance characteristics, advantages, and challenges. Additionally, food safety applications of nucleic acid-based biosensors will be discussed.

\section{BIOSENSORS AS MEDICAL DEVICES}

Numerous applications of biosensing techniques have been reported in healthcare and clinical fields. Throughout the history of biosensing techniques, there has been an intrinsic association with medical devices and, in many cases, has prompted the development of novel biosensors $(6,7)$.

The earliest reported biosensor was the Leyland Clark coated oxygen electrode, which contained the glucose oxidase enzyme and was helpful measuring levels of blood glucose $(7,18)$. The glucose oxidase enzyme converts the glucose substrate into gluconolactone and hydrogen peroxide, with an important oxygen consumption feature. The drop in the dissolved oxygen that could be measured, and indirectly, the levels of blood glucose could be calculated $(7,18)$. This biosensing principle of immobilizing the glucose oxidase enzyme can be applied to almost any oxidase enzyme, enabling the development of other enzyme-based biosensors with clinical applications (19-21). Currently, glucose biosensors continue to be used; some devices are 
used in situ as a drug delivery system to monitor and regulate the patient's glucose levels. These biosensors have been applied to diagnose and monitor diabetes mellitus, where precise control over blood glucose levels is required $(22,23)$.

Moving on to antigen-antibody interactions, the first commercially available immunoassay was responsible for detecting the presence of human chorionic gonadotrophin ( $\mathrm{hCG}$ ), also known as the home pregnancy test. Initially, it was only possible to detect the presence or absence of hCG, displaying the result as pregnant or not. But later models have used colorimetric quantitation to assess hCG levels and estimate the elapsed time since conception (6).

Biosensors for protein determination can be involved in detecting diseases and pathogenic microorganisms such as viruses, bacteria, parasites, and fungi, and even in the identification of antimicrobial resistance patterns (24-30). Some of the most important proteins detected using biosensors are the p53 protein, expressed in more than $90 \%$ of cancers $(31,32)$, the Tau protein, useful for the diagnosis of Alzheimer's (33), and C-reactive proteins, involved in inflammation processes (34). Recently, the monitoring of antigenic proteins of SARS-CoV-2 has been reported, which could be implemented for the rapid detection of Covid-19 (35). Additionally, there are biosensors used to detect RNA-viruses that could have potential application in detecting Covid-19 which use nucleic acids as biorecognition elements (for example, aptamers and antigen-Au/Ag nanoparticles) and can be coupled to a variety of transducers such as electrochemical, optical, and surface plasmon resonance (36). Biosensors are also useful for detecting peptides, which can be biomarkers for early disease detection. For example, the determination of beta-amyloid peptides could enable an earlier diagnosis of Alzheimer's disease (37).

The main difficulty in the biosensor design is identifying the target analyte related to the disease. Hepatocellular carcinoma ( $\mathrm{HCC}$ ) requires the earliest diagnosis due to the limited therapeutic options. The diagnosis is based on the level of $\alpha$-fetoprotein, but their up-regulation is also a consequence of other liver diseases and pancreatitis; for this reason, it is considered a biomarker of low sensitivity and specificity. Several proteins have been identified as related to HCC as $\alpha$-fetoprotein-L3, annexin-2, des-gamma-carboxyprothrombin, Golgi protein-63, glypican-3, midkine, osteopontin, squamous cell carcinoma antigen, thioredoxins, and urokinase plasminogen activator receptor. Most of these analytes are of low abundance and will require a biosensor with high sensitivity. This is an example of the importance of identifying the biosensor target analyte, which is the major issue to resolve (38.

The development of whole cell-based biosensors has rapidly accelerated, demonstrating their huge potential in biomedical diagnosis and analysis of environmental and food matrices $(15,39,40)$. The major advantages of these systems are high sensitivity and selectivity, reagentless rapid detection, and cost-effective testing during routine inspections or at the points of care (25). For example, a novel biosensor has been designed to detect Staphylococcus aureus, a pathogen responsible for causing foodborne diseases (41).

Moreover, other reported biosensors include a surface plasmon resonance-based biosensor optimized to monitor hemoglobin levels in human blood, a biosensor for quantifying cardiac markers in undiluted serum, and a microfluidic impedance platform for controlling endothelin-induced cardiac hypertrophy, among others $(42,43)$. In particular, in the drug discovery and development pipeline, there are numerous reports of fluorescent biosensors used for hit identification, lead optimization, and pharmacokinetic evaluations (44-48).

\section{BIOSENSORS IN FOOD AND ENVIRONMENTAL MONITORING}

Water environments contain numerous pollutants such as petroleum-related products, pesticides, pharms, drugs, etc. The pharmaceutical industry, hospitals, geriatric and healthcare houses are the main sources of drug pollutants in water that affect humans, plants, and animals(49). Antibiotics, hormones, analgesics, and cytostatics or $\beta$-blockers have been associated with a high risk of negative effects on the environment and public health, such as reproductive impairment (50-52), increased incidence of cancer, and development of antibioticresistant bacteria (53). Moreover, increased toxicity due to synergistic effects has also been reported (54). Since biosensing techniques could offer important advantages, rigorous validation studies with environmental samples should be carried out (55).

The use of biosensing techniques has been reported in monitoring residues from veterinary drugs used in food-producing animals (55). Endocrine-disrupting chemicals are contaminants of water and soil; estrogens can interfere with the 
balance of hormone metabolism in the organism, affecting physiological functions such as growth, development, and reproduction. In addition, synthetic estrogens are mostly used in contraception or hormone therapy(56). Exogenous substances in the environment can mimic the effects of estrogens, such as pesticides, veterinary drugs, feed additives, industrial chemicals, etc. The aptamers have great potential in biosensing to detect estrogens. Kim et al., identified DNA aptamers bound to 17b-estradiol and were applied to an electrochemical sensing platform to construct an electrochemical aptasensor with high sensitivity and specificity to $17 \mathrm{~b}$-estradiol (57). Similarly, Jo et al., isolated single-stranded DNA aptamers that specifically recognize bisphenol A (58). Ma et al., fabricated an electrochemical aptasensor with AuNPs coated boron-doped diamond-modified electrodes to immobilize aptamers. Bisphenol A biosensor had a linear range of $1.0 \times 10^{-14}$ to $1.0 \times 10^{-9} \mathrm{M}$ and a detection limit of $7.2 \times 10^{-15} \mathrm{M}$. The aptasensors were applied to measure commercial milk samples containing bisphenol $A$; the aptasensor was able to detect this estrogen with recoveries of $92-108 \%$ (59). The electrochemical aptasensor based on gold nanoparticles dotted graphene nanocomposite film modified electrode showed a linear concentration between 0.01-10 $\mathrm{mM}$ with a detection limit of 5 $\mathrm{nM}$. The bisphenol A content in liquid milk and milk powder was determined, being the average recovery of $105 \%$. Abnous et al., developed an electrochemical aptasensor forming a bridge between the aptamer and its complementary strand; this aptasensor selectively detected bisphenol $A$ with 0.08-15 $\mathrm{nM}$ detection range and a detection limit of $15 \mathrm{pM}$. This aptasensor allowed to determine the bisphenol content in grape juice samples; the recoveries were $88.6-97.3 \%$ (60).

Nameghi et al., developed an electrochemical aptasensor for measuring 17b-estradiol; in this system, split DNA aptamers that bind 17b-estradiol were used as recognition elements to construct a split1-17b-estradiol-split2 complex. This aptasensor was tested on the milk samples spiked with $17 \mathrm{~b}$-estradiol, the detection limit was $0.7 \mathrm{pM}$ with a linear range of 0,003-9 $\mathrm{nM}$, and the recoveries were $89.4 \%$ to $101.7 \%(61)$.
Rathnayake et al., isolated the bacterial strain $B$. megaterium from the soil; this bacterium was transformed with a GFP plasmid. The transformed bacteria VR1 was immobilized in a sol-gel matrix to be used as a whole-cell bacterial biosensor. The biosensor is based on the percentage survival of bacteria VR1 in the presence of different heavy metals. The results showed that bacteria strain was more sensitive to $\mathrm{Cu}$, followed by $\mathrm{Cd}$ and $\mathrm{Zn}$. The fluorescence signal depended on the cell density, and the optimal response was obtained with a cell density of 0.09 . The linear range of the effective concentration curve of the survival of $B$. megaterium VR1 showed a coefficient of determination (R2) of more than 0.95 and $p=1.4 \times 10^{-5} ; 1.1 \times 10^{-6} ; 7.2 \times 10^{-9}$ for $\mathrm{Cd}, \mathrm{Cu}$, and $\mathrm{Zn}$ respectively at $95 \%$ confidence. The interaction between the toxicant and the microorganisms is inherent of biological relevance, and the response entirely depends on the individual organism used (62).

\section{NUCLEIC ACID-BASED BIOSENSORS}

A nucleic acid-based biosensor can be defined as a device that brings together a nucleic acid as the biorecognition element and a transducer responsible for converting the biorecognition event into a measurable signal (4). Recently, these biosensors are gaining importance due to their broad usefulness in monitoring parameters, which is very important in the fields of clinical diagnosis, drug development, and the food industry, among others. Nucleic acid molecules can be classified as DNA, RNA, peptide nucleic acid (PNA), and aptamers. The principle behind nucleic acid-based biosensors lies in the biorecognition event, based on the hybridization mechanism (Figure 3). This event occurs when the probe sequence immobilized on the transducer has been designed to complement the target sequence and to exhibit selectivity for non-complementary sequences $(5,7,63)$. On the contrary, in the case of aptamers, the detection principle is more similar to antigen-antibody or receptor-ligand interactions; it is usually accompanied by conformational changes in the aptamer (7). 


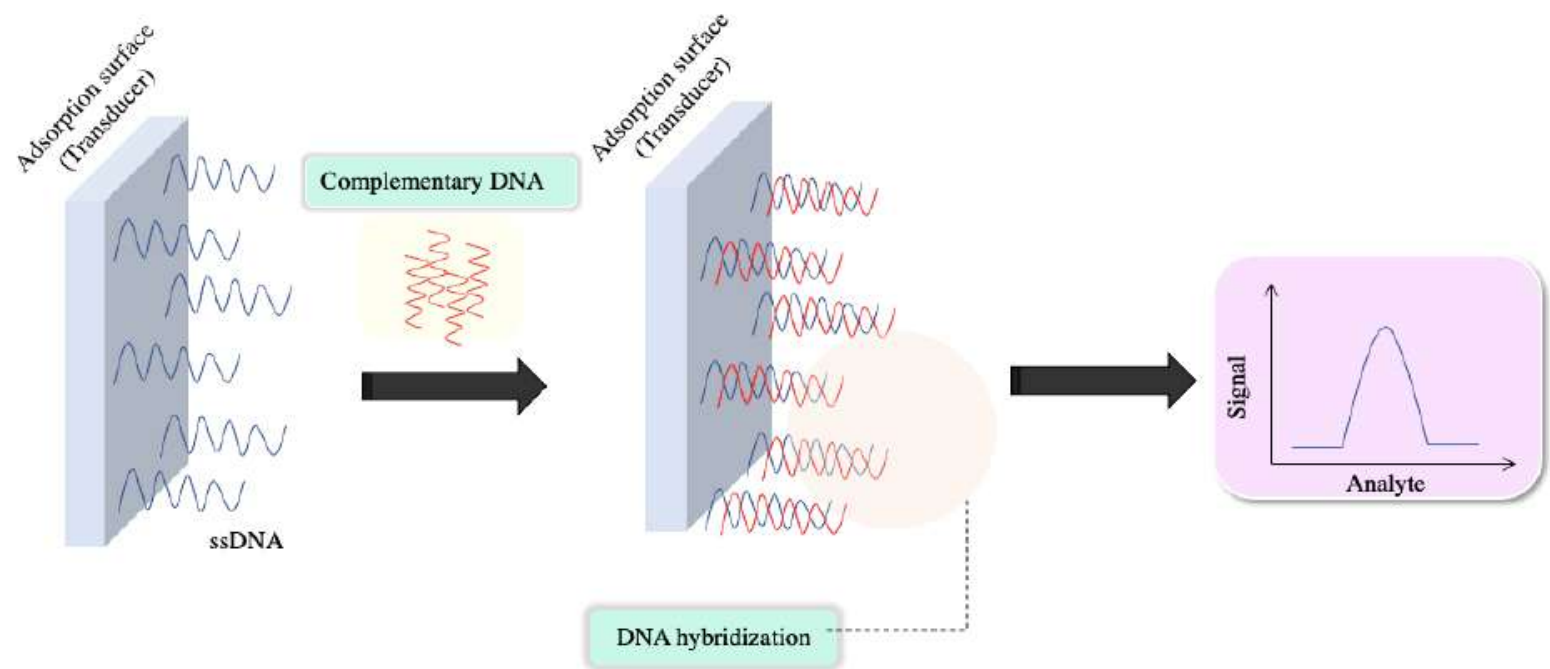

Figure 3. The biorecognition event in nucleic acid-based biosensors for the detection of nucleic acids corresponds to the hybridization process between the DNA probe and the target strands. (Adapted from (3-5)).

It is also possible to classify the biosensor depending on the biorecognition element: DNA-based biosensors could be single-stranded DNA (ssDNA), also known as DNA aptamer, double-stranded DNA (dsDNA), stem-and-loop DNA, and triplexhelical DNA. Regarding RNA-based biosensors, the biorecognition element could be single-stranded RNA (ssRNA), also known as RNA aptamers. In addition, PNA has also been reported as an alternative biorecognition element (14).

\subsection{Aptamers}

In biochemistry, these are a family of single-stranded DNA or RNA oligonucleotides. In biosensing techniques, aptamers are considered a type of biorecognition element under the nucleic acidbased biosensors category. Aptamers can bind to targets such as proteins, drugs, peptides, and cells. DNA aptamers have been reported to exhibit high selectivity and affinity, binding to diverse bioanalytes such as nucleic acids, cells, proteins, viruses, and small molecules such as aflatoxin B1, cocaine, dopamine, and metal ions. They have also been shown to have an ability to differentiate between enantiomers. However, RNA aptamers usually exhibit higher binding affinity than DNA aptamers compared to the same target sequence, owing to the 2 ' hydroxyl functional group in the RNA aptamers (64-67).

The biorecognition event, in this case, the binding between the aptamer and the target ligand, induces a conformational change in the secondary and tertiary structures of the aptamer. Therefore, in aptamer-based biosensors, these structural changes are responsible for generating an often-easy-todetect signal $(7,64)$. The aptamer detection model has certain similarities with the antigen-antibody model regarding the binding pattern mechanism. But aptamers have a major advantage: their threedimensional structure enables high affinity and binding specificity.

Aptamers can resist harsh environmental conditions, be stored without special requirements, and be obtained with high reproducibility and low production costs $(14,68,69)$. The major challenge in developing aptamer-based biosensors is the identification of the specific ssDNA/RNA sequences capable of binding to the target ligand. Consequently, the aptamer sequence is chosen by combinatorial methods and libraries of random oligonucleotides (7). The selection of aptamer candidates is made by an in vitro method called the systematic evolution of ligands by exponential enrichment (SELEX). The SELEX process aims to produce specific oligonucleotides that bind to a predefined target. It is a versatile tool because it allows some variants to be developed to optimize aspects such as the efficiency, specificity, and affinity of the aptamer. As shown in Figure 4, the SELEX process begins with generating a library containing around $10^{13}$ to $10^{15}$ random oligonucleotide sequences of 30-80 bp each. Second, the binding or incubation step begins as the random library 
sequences are incubated with the immobilized target molecule. The nucleic acids that bind to the target are considered aptamers, whereas the unbound nucleic acids are simply filtered out of the solution. Third, through an elution process, the separation of nucleic acids bound to the target occurs. Fourth, the obtained aptamers are copied using PCR in a process called amplification. A new optimized library is created, after which the newly synthesized library is used to start another cycle of the SELEX process (7).

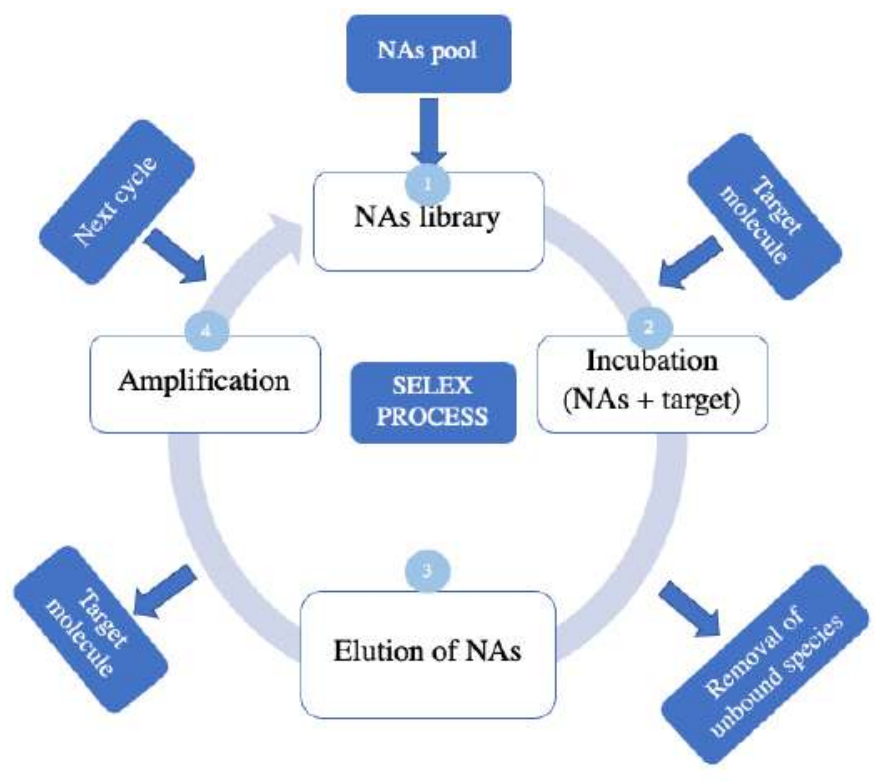

Figure 4. Representative scheme of the SELEX process. (Adapted from $(5,7)$

The competitive binding in each new cycle of the SELEX process enables the identification of the species with the highest binding affinities. It is possible to introduce molecules with similar structures to optimize the affinity $(64,70,71)$.

Aptamers make possible the development of new biometric tools for food safety applications, detecting microorganisms, cadmium ions, mycotoxins, pesticides, and small molecules (71-74).

\subsection{Riboswitches}

Riboswitches are mRNA elements that bind to specific metabolite ligands and regulate mRNA expression on the same molecule that the riboswitch is coded in. Riboswitches are composed of an aptamer domain and an expression platform. The aptamer domain (synthetic or natural) acts as a receptor, because it includes the binding site for a small ligand such as a metabolite or a metal ion. The binding event between the aptamer domain and the ligand triggers a conformational change. This switching in the secondary structure of the riboswitch is responsible for modulating gene expression $(75,76)$. Conceptually, riboswitches are considered to be an extension of aptamer-based biosensing technology (77-79).

Riboswitches can directly bind with small molecules such as ions, small metabolites, or uncharged tRNA. Additionally, riboswitches can recognize different molecules with high specificities, such as peptides, coenzymes, carbohydrates, amino acids, metallic ions, and nucleic acids (77-80). Riboswitches can discriminate among molecules with similar structures, which makes them a promising alternative in biosensing techniques. For example, a novel biosensor capable of discriminating between adenosylcobalamin and methylcobalamin has successfully been applied to monitor adenosylcobalamin concentrations as a biomarker of the metabolic stage in the cell cycle of $E$. coli cultures $(75,81)$.

\subsection{PNA}

The peptide nucleic acids (PNAs) are synthetic DNA analogs in which a neutral peptide-like backbone composed of repeated $\mathrm{N}$-(2-aminoethyl) glycine units substitute for the sugar-phosphate backbone of the natural nucleic acids $(82,83)$. Advantages of PNA over natural nucleic acid analogs DNA and RNA include higher stability, such as against enzymatic cleavage, enhanced selectivity, neutral charge, and the possibility of synthesizing it using regular peptide solid-phase synthesis protocols (83-86).

PNA-based RNA or DNA detection biosensors have been developed for early disease diagnoses such as cancer, food safety applications, and environmental monitoring $(87,88)$. Specifically, in the food safety field, a label-free PNA-based biosensor for ultrasensitive DNA detection with a graphene oxide transducer has been developed for microorganism detection (87-89).

\section{IMMOBILIZATION TECHNIQUES}

Nucleic acid-based biosensors are developed by immobilizing nucleic acids to a solid support and their coupling to a transducer. The immobilization process aids in probe orientation and accessibility to the target element (90-92). DNA is frequently preferred as the biorecognition element over other nucleic acid molecules because of its advantages, including signal and target amplifications and 
chemically stable and reusable bio-recognition layers formation (90). Therefore, this section focuses on immobilization techniques of DNA-based probes.

In the design of a DNA-based biosensor, it is important to consider the DNA immobilization process before developing the sensor because it significantly influences the efficiency and response of the biosensor. Immobilization methods depend on the purpose of the biosensor and the nature of the transducer. In order to be considered an ideal immobilization, the transducer surface must: 1) exhibit specific binding to the DNA probe in solution, and 2) maintain the capacity to detect the presence of the analyte (90).

\subsection{Physical adsorption}

Immobilization through physical adsorption can be possible thanks to non-covalent interactions between the biorecognition element and the transducer surface, as shown in Figure 5A (93). A simple, well-known method for DNA immobilization is the glassy carbon electrode, which can be immersed or dropped into the probe solution and then left to dry. This is considered the simplest method because it does not require chemical reagents or modifications of the nucleic acid probe $(94,95)$.

The $\mathrm{MoS}_{2}$ nanosheets possess fluorescence quenching capability and different affinity towards ssDNA and dsDNA. A dye-labeled ssDNA was adsorbed on $\mathrm{MoS}_{2}$ nanosheets with quenched fluorescence; after adding the complementary target DNA, hybridization weakened the van der Waals interaction between nucleobases and nanosheet leading to desorption of DNA strand and restoration of fluorescence. This MoS2 nanosheetbased biosensor exhibited excellent performance for the rapid and homogeneous analysis of DNA, with a detection limit of $500 \mathrm{pM}$. The biosensor detection limit $(5 \mu \mathrm{M})$ was increased using an adenosine aptamer as probe DNA, and a detection limit was achieved (96).

Other transition metal nanosheets, such as $\mathrm{WS}_{2}$ $\mathrm{MnO}_{2}$, and $\mathrm{Ta}_{2} \mathrm{NiS}_{5}$ nanosheets, also exhibit high quenching efficiency and physisorption properties towards dye-labeled ssDNA. Zhang group adapted the sensing platform for multiplexed DNA detection by simultaneously adsorbing two different ssDNA probes targeting Influenza A virus subtype H1N1 gene and subtype H5N1 gene onto TaS2 nanosheets. The probes only responded to the specific target sequence and emitted corresponding fluorescence (single-Layer Transition Metal Dichalcogenide Nanosheet-Based Nanosensors for Rapid, Sensitive, and Multiplexed Detection of DNA (97).

In electrical adsorption, before immobilization of the DNA probes can occur, a potential that generates roughness and hydrophobicity must be applied to the surface of the carbon electrode. The positive charge of the electrode surface and the negative charge found in the phosphate group of nucleic acids enables probe adsorption (67). Electrochemical DNA-based biosensors are ideal for detecting pathogens that cause foodborne diseases, because of their high reproducibility, low detection limit, and wide linear dynamic range (98).

\subsection{Covalent attachment}

Covalent attachment aims to create a bond between DNA probes and the transducer's surface through hybridization (Figure 5B). This interaction will become more stable over time (99).

In this field, it has been found that the use of cellulose nanofiber can have biosensor applications. Wang et al., (99) worked on the design of a dual-function cellulose nanofiber-based bionic biosensor. That investigation aimed to graft a DNA aptamer onto the surface of a dual-function cellulose nanofiber (CNF) to obtain a biosensor capable of detecting trace levels of $\mathrm{Ag}^{+}$. They demonstrated good sensitivity, with a LOD of $10^{-6} \mathrm{nM}$ for $\mathrm{Ag}^{+}$, even in the presence of other metal ions. At the same time, this biosensor was able to detect acetylcholinesterase.

\subsection{Formation of the avidin-biotin complex}

Both avidin and streptavidin are quaternary proteins, and they have similar properties, such as weight and structure, and biotin is a vitamin with a strong affinity for avidin and streptavidin. The formation of an avidin-biotin complex or a streptavidinbiotin complex represents a strong non-covalent interaction (Figure 5C) (100).

Chung et al., (101) designed an electrochemical DNA-based biosensor to detect the influenza type A virus by conjugating a biotinylated DNA probe (5'-biotin-ATG AGT CTT CTA ACC GAG GTC GAA$\left.3^{\prime}\right)$ and an avidin-modified glassy carbon electrode. Different concentrations of target DNA were employed. The calculated LOD was $8.51 \times 10^{-14} \mathrm{M}$, and good sensitivity for detecting the target DNA was demonstrated. 
Terse-Thakoor et al., designed an electrical biosensor using a streptavidin-biotin system, graphene nanogap electrodes, and gold nanoparticles (102).
The results showed a sensitivity of $0.3 \mu \mathrm{A} / \mathrm{nM}$ and a LOD of 0.25 pM for streptavidin detection.

(A)
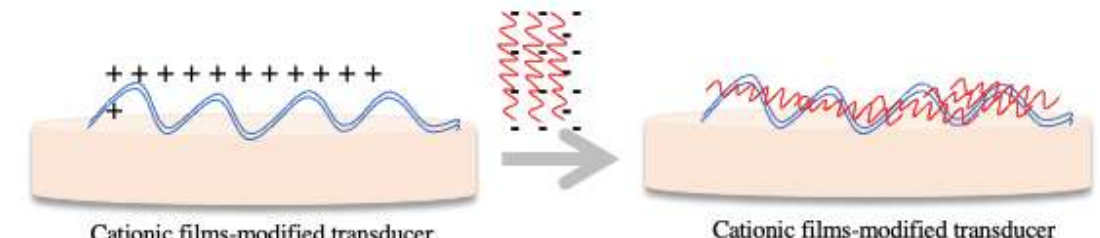

Cationic films-modified transducer

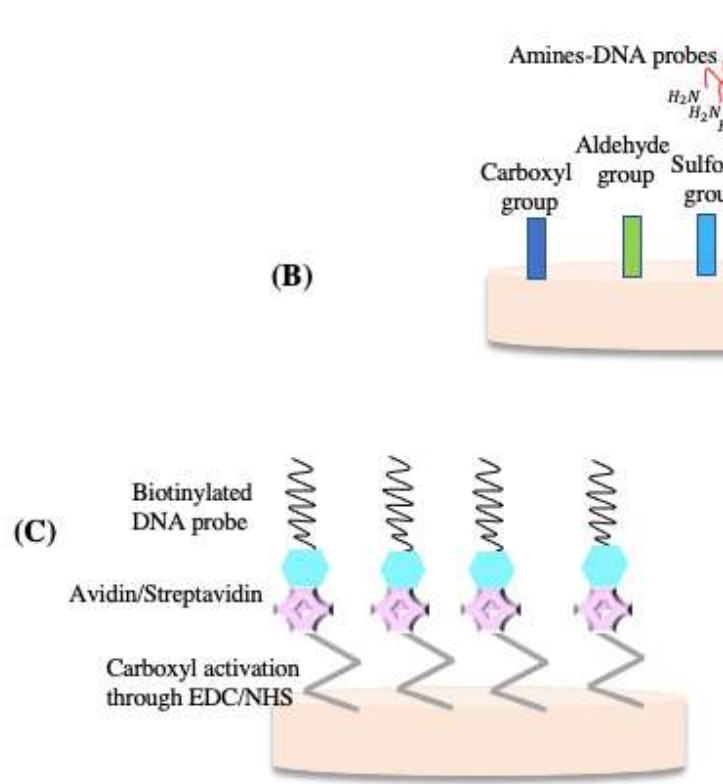

(C.1)

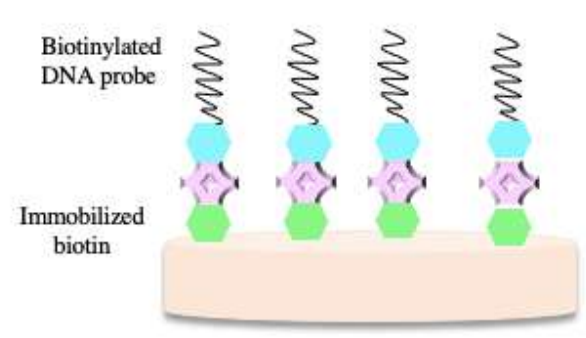

(C.2)

Figure 5. Schematic representation of DNA immobilization techniques: A) Physical adsorption. B) Covalent attachment C) Immobilization of biotinylated DNA-probes C.1) Formation of the avidin/streptavidin complex C.2) Biotin/avidin or biotin/streptavidin complex. Adapted from (103).

\section{BIOSENSORS FOR NUCLEIC ACID DETECTION}

The study and detection of single molecules such as DNA have gained enormous relevance and have numerous applications in the clinical field (2). The detection principle of nucleic acids using a nucleic acid-based biosensor relies on the hybridization reaction (Figure 3 ) or target interactions in the case of aptamers $(14,15)$. Moreover, nucleic acidbased biosensors for nucleic acid detection can be classified according to the biorecognition element, the structure of the bioreceptor, or the type of transducer (Figure 6).

Accurate, rapid, and sensitive detection of nucleic acids in complex matrices plays an important role but remains challenging $(13,104)$. One of the most investigated strategies for improving sensitivity is signal amplification, which refers to optimizing the biomolecules immobilized in the bioreceptor to enhance signal output and reliability (9). Particular examples of biosensors that employ signal amplification techniques will be addressed below in this chapter. 


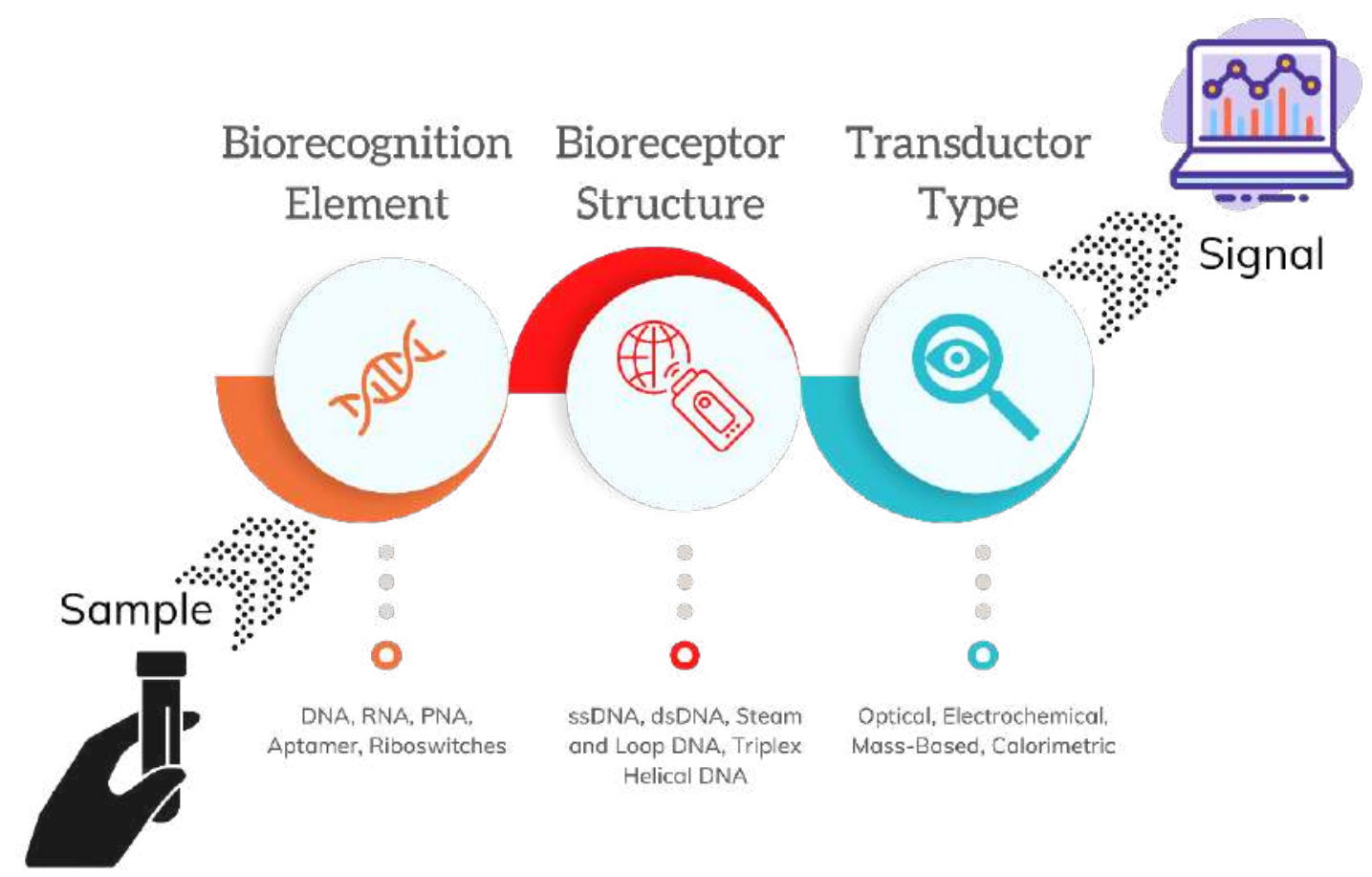

Figure 6. Classification of nucleic acid-based biosensors for nucleic acid detection. Adapted from (3-7).

It is important to mention that if the biorecognition event involves hybridization and the biosensor employs an electrochemical transducer, the detection can be mediated by two different pathways: label-free or labeled detection. Labelfree electrochemical detection of DNA hybridization is based on intrinsic DNA signals of electroactive DNA bases such as guanine or adenine. On the contrary, labeled electrochemical detection of DNA hybridization employs redox-active probes as labels, which can selectively bind with dsDNA/ ssDNA. The objective of these pathways is to obtain a measurable decrease/increase in the oxidation/ reduction peak current, through electroactive DNA bases or electrochemical labels.

In 2020, Wang et al., developed a novel electrochemical biosensor for nucleic acid detection, using the stable free nitronyl nitroxide monoradical 2,2,6,6-tetramethylpiperidine 1-oxyl (TEMPO) as an electrochemical label. TEMPO constitutes a rational choice because of its high electrochemical activity, a clear electrochemical signal in aqueous solution, high stability, low pollution, and high utilization rate $(13,105,106)$. Thus Wang et al., reported the first use of TEMPO as an electrochemical label for ssDNAdetection and highlighted its good performance (13). The biorecognition element used was PNA, which was immobilized on the surface of a glassy carbon electrode. Under optimal conditions, the linear range was found to be $10 \mathrm{pM}$ to $100 \mathrm{nM}$, and the LOD was calculated as $2.57 \mathrm{pM}$. The specificity of PNA conferred high selectivity to the biosensor. Likewise, the repeatability and storage stability were verified. Regarding the analytical performance of this method in complex serum samples, it was confirmed that the biosensor could effectively exclude interfering substances and detect the target DNA (13).

Addressing the issue of early disease diagnosis, in 2020, Moccia et al., developed the first paper-based electrochemical PNA biosensor for the detection of miRNA-492, a suggested biomarker for pancreatic ductal adenocarcinoma (PDCA) $(107,108)$. It is well known that clinicians face a great challenge concerning the silent progression of PDCA due to the complexity of an early diagnosis, which delays timely treatment (109-111). This reported paper-based biosensor was built on a miniaturized, sensitive, and robust paper-based platform by screen-printing a three-electrode system on previously wax-patterned office paper. Thus, the screen-printed electrodes were built from silver/silver chloride ink for the pseudo-reference electrode and graphite ink for the counter and working electrodes. Therefore, the electrochemical transducer was based on a graphite working electrode, but it had a modified surface with gold nanoparticles, which enabled anchor points and controlled PNA immobilization (11). 
The selected biorecognition element was PNA because of its enhanced binding affinity detecting DNA and RNA molecules. Moccia et al., achieved a stable and effective duplex formation between PNA and miRNA-492, mainly by designing the PNA probe to fully complement miRNA-492 with antiparallel orientation $(11,112)$. Later, the probe density was optimized for the concentration of $100 \mathrm{nM}$ of PNA probe in the presence of a $50 \mathrm{nM}$ miRNA-492 target, where the highest signal variation (33\%) and lowest RSD (18\%) were recorded. The linear range was between 50 and $100 \mathrm{nM}$, and the LOD was calculated as $6 \mathrm{nM}$ (11). The selectivity was challenged by adding sequences with one- or two-base mismatches or a fully random sequence. The biosensor showed excellent selectivity towards the target analyte, with no significant signal change even when the interfering sequences were present at a higher concentration Additionally, the paper-based biosensor was tested in undiluted blood serum as a complex matrix, achieving a LOD of $22 \mathrm{nM}$. Therefore, potential applicability for early PDCA diagnosis based on the quantification of miRNA-492 could be further explored (11). Ultimately, some unique advantages of a paper-based biosensor must be emphasized besides matching the ASSURED criteria, such as sustainability, cost-effective fabrication, portability, and reduction in waste management $(10,113)$.

Li et al., reported a DNA nanostructure-based platform that enables a recyclable biointerface for ultra-sensitive detection of nucleic acid. The probe DNA was, in fact, a nanostructure composed of chemically cross-linked branched DNA (CCLB-DNA) designed to increase probe distance and exposure of the interface in the solution phase. As a result, the signal was significantly enhanced, possibly because of an increased probability of collision between the DNA probes and the target DNA (T-DNA), further leading to an elevated capture rate of T-DNA. The rationale for designing a biorecognition platform with increased probe distance was based on a previous kinetic and thermodynamic analysis that revealed an enhanced hybridization process (114). The transducer employed was an electrical device that senses frequency changes of a quartz crystal resonator, which is known as a quartz crystal microbalance (QCM). While it enables label-free, sensitive DNA detection, quartz crystal chips have exhibited limited reuse capacity. Besides the elevated cost and pollution of the existing regeneration strategies, limitations include time consumption, inefficiency, or destruction to the functional layer (114-116).
DNA was immobilized on the gold surface of the quartz crystal through Au-S bonds. Frequency shifts generated by the hybridization of the target T-DNA with the CCLB-DNA probes were amplified by further hybridization of the DNA functionalized $\mathrm{Fe}_{3} \mathrm{O}_{4}\left(\mathrm{M}-\mathrm{Fe}_{3} \mathrm{O}_{4}\right)$ nanoparticles with the other end of the T-DNA. Finally, the chip was immersed in a urea solution in order to release the T-DNA and $\mathrm{M}-\mathrm{Fe}_{3} \mathrm{O}_{4}$, demonstrating that the recognition layer was easily regenerated. No frequency attenuation was observed, and the stability was maintained after four cycles of detection and recovery. The excellent reusability characteristics exhibited by this biosensor make it an excellent prospect for engineering recyclable biointerfaces. Regarding the performance characteristics, the LOD was reported to be as low as $500 \mathrm{fM}$, and the concentration exhibited a linear relationship with the frequency shifts in a range of concentrations from $500 \mathrm{fM}$ to 1 $\mu \mathrm{M}$ (114). It is important to point out that this CCLBDNA-based biosensor successfully overcomes the alleged "size dilemma" of nanoscale sensors, which refers to a reduced collision probability between probes and target molecules due to the restricted quantity of immobilized probes that can fit in the limited space available (114,117-119).

Tian et al., developed a graphene field-effect transistor (G-FET) biosensor with PNA probes for trace RNA detection. A control biosensor using traditional DNA probes was also manufactured to evaluate the advantages of the developed biosensor that employs PNA. The DNA probes exhibited the limitations of long hybridization time, background electrical noise, and relatively poor specificity (63). It was found that the PNA probe G-FET (PNA-GFET) biosensor achieved a LOD of $0.1 \mathrm{aM}$, while the DNA probe biosensor exhibited a LOD three orders higher (100 aM). An important advantage conferred by the PNA probe over the biosensor was enhanced sensitivity and specificity compared to the control device. A large electrical response of the PNA-G-FET sensor to the target RNA was reported. Since the hybridization of PNA-RNA is much faster than that of DNA-RNA, the authors demonstrated that the PNA-G-FET could shorten the detection time. The linear response displayed by the PNA-G-FET, was from $0.1 \mathrm{aM}$ to $1 \mathrm{pM}$, while for DNA probe-modified G-FET, it was from 100 aM to 1 pM. These results demonstrate that the PNA probe could be ideal for the G-FET biosensors for nucleic acid detection, associated with improvements in the sensing performance (63). It is important to highlight three fundamental theoretical aspects 
considered by Tian et al., that led to the design of their PNA-G-FET biosensor: (1) PNA probes can enhance the specificity of hybridization and shorten the detection time (120), (2) field-effect transistor sensors improve sensitivity, analysis efficiency, detection cost, and accuracy, and (3) graphene has a high specific surface area and elevated electron mobility, allowing easy interaction with biomolecules through $\pi-\pi$ bond stacking $(63,121)$.

Pathogen diagnosis is essential for disease prevention and proper treatment (122). PCR is usually the preferred method for clinical pathogen diagnosis; however, it entails rigorous requirements, such as well-equipped laboratories, trained personnel, extensive time consumption, and complicated sample preparation (123). Therefore, alternative and competitive detection strategies would be desirable.

For example, Dengue and Zika infections pose a great threat to human life, represented by their high morbidity and mortality rate. These infections usually entail a difficult clinical diagnosis due to similar clinical manifestations (124-126). Dengue and Zika viruses have certain similarities that would make simultaneous detection an essential tool for providing a timely treatment: both of these viruses share the transmission vector of the Aedes mosquitoes, sharing the geographical distribution as well as the seasonal correlation (127). Dengue and Zika diagnoses are usually based on virus isolation cultures, enzyme-linked immunosorbent assays (ELISA), and genomic RNA detection using PCR. However, simultaneous and synchronous detection for multiplexed nucleic acids has rarely been reported $(127,128)$.

In 2017, Xie et al., (127) reported a single-stranded probe DNA bioreceptor that simultaneously detects RNA sequences of Dengue and Zika viruses through a fluorescence transducer. They synthesized a watersoluble and stable metal-organic framework (MOF) that exhibits high affinity toward carboxyfluorescein or 5(6)-carboxyrhodamine, triethylammonium salt (ROX)-tagged single-stranded probe DNA through $\pi$ stacking and electrostatic interactions, thus quenching the fluorescence of the tag. Fluorescence transducers have been shown to exhibit high sensitivity and rapid response time. In contrast, MOFs as quenching platforms for fluorophorelabeled nucleic acid detection have been reported to enhance the sensitivity and reduce background noise (129-131).

Employing a detection time of $36 \mathrm{~min}$ and $2 \mathrm{~min}$, the calculated LOD was 332 and 192 pM with the single detection method, and 184 and $121 \mathrm{pM}$ with the synchronous detection method for Dengue and Zika viruses, respectively. Both assays were highly specific, with no interference by other mismatched RNA sequences, even down to single-base mismatched RNA sequences. There was no crossreaction between the two probes for synchronous detection. The reported linear range was from 0 to $60 \mathrm{nM}$ (127).

A comprehensive summary of the performance characteristics of the discussed biosensors is shown in Table 1.

Table 1. Summary of performance characteristics for the discussed biosensors for nucleic acid detection.

\begin{tabular}{|c|c|c|c|c|c|c|}
\hline Authors & $\begin{array}{l}\text { Biorecognition } \\
\text { element }\end{array}$ & Analyte & Transducer & LOD/ Linear range & Additional & $\begin{array}{l}\text { Field of } \\
\text { application }\end{array}$ \\
\hline $\begin{array}{l}\text { Wang et } \\
\text { al., } 2020\end{array}$ & PNA & ssDNA & GCE & $2.57 \mathrm{pM} / 10 \mathrm{pM}$ to $100 \mathrm{nM}$ & $\begin{array}{l}\text { Electrochemical } \\
\text { label: TEMPO }\end{array}$ & NS \\
\hline $\begin{array}{l}\text { Moccia et } \\
\text { al., } 2020\end{array}$ & PNA & $\begin{array}{c}\text { miRNA-492 } \\
\text { suggested } \\
\text { biomarker for PDCA }\end{array}$ & $\begin{array}{l}\text { Graphite working } \\
\text { electrode/surface of } \\
\text { gold nanoparticles. }\end{array}$ & $6 \mathrm{nM} / 50$ to $100 \mathrm{nM}$ & $\begin{array}{l}\text { Complex matrix: } \\
\text { Undiluted blood } \\
\text { serum (LOD } 22 \mathrm{nM} \text { ) }\end{array}$ & $\begin{array}{l}\text { Early } \\
\text { detection of } \\
\text { PDCA. }\end{array}$ \\
\hline $\begin{array}{l}\text { Li et al., } \\
2018\end{array}$ & $\begin{array}{c}\text { DNA } \\
\text { nanostructure- } \\
\text { based platform }\end{array}$ & Nucleic acids & QCM & $500 \mathrm{fM} / 500 \mathrm{fM}$ to $1 \mu \mathrm{M}$ & N.A & $\begin{array}{c}\text { Recyclable } \\
\text { biointerfaces }\end{array}$ \\
\hline $\begin{array}{l}\text { Tian et al., } \\
2020\end{array}$ & PNA & RNA & G-FET & $0,1 \mathrm{aM} / 0.1 \mathrm{aM}$ to $1 \mathrm{pM}$ & N.A & NS \\
\hline $\begin{array}{l}\text { Xie et al., } \\
2017 .\end{array}$ & ssDNA & RNA & Fluorescence MOF & $\begin{array}{l}184 \mathrm{pM} \text { Dengue; } 121 \mathrm{pM} \\
\text { Zika/0 to } 60 \mathrm{nM}\end{array}$ & ROX and FAM & $\begin{array}{c}\text { Early disease } \\
\text { diagnosis }\end{array}$ \\
\hline
\end{tabular}

TEMPO: nitronyl nitroxide monoradical 2,2,6,6-tetramethylpiperidine 1-Oxyl; PDCA: pancreatic ductal adenocarcinoma; QCM: Quartz Crystal Microbalance; MOF: metalorganic frameworks; FAM: carboxyfluorescein; ROX: triethylammonium salt; G-FET: Graphene Field-Effect Transistor. GCE: Glass Carbon Electrode. Ns: Not specified. 
In general, the performance characteristics of the biosensors mentioned above are aligned with the ASSURED criteria, demonstrating short detection time, competitive LOD, linear range, and specificity. Most studies emphasize parameter optimization, assessment of storage stability, regeneration potential, reproducibility of manufacture, and application to complex/real matrixes. The authors clearly explained the theory and rationale supporting the designed biosensors, which were very promising for develop new biosensing techniques.

Even though the nucleic acid-based biosensors reviewed here share a nucleic acid analyte and the fundamental hybridization mechanism (except aptamers), the reported detection platforms are very diverse. The development of materials for biosensing platforms needs to be acknowledged: they are essential for novel biosensor designs and constitute a constantly expanding field.

\section{NUCLEIC ACID-BASED BIOSENSORS IN DETECTION OF FOODBORNE PATHOGENIC AGENTS}

Food contamination can be categorized according to the nature of the causal agent: bacteria, viruses, parasites, prions, and chemicals, among others (132). Diverse biosensors have been designed to detect foodborne pathogenic agents, spanning the range from enzyme-based to immune and thermal-based mechanisms. Among nucleic acid-based biosensors, reported analytes related to food contamination include proteins, nucleic acids, and ions. Huo et al., (132) reported a nucleic acid-based biosensor to detect food contaminants that provides a rapid food-safety analysis.

Bacterial contamination in food and water is a serious public health problem worldwide associated with increased animal and human mortality and higher health expenses (133). Most bacterial foodborne diseases have similar symptoms, including diarrhea, emesis, and fever, challenging timely detection and incidence estimation. According to the WHO, approximately 600 million illnesses and 420,000 deaths occur annually due to foodborne pathogenic bacteria $(134,135)$. However, these data could be grossly underestimated because of misdiagnoses, under-reporting (in minor outbreaks), and inadequate sample collection or analysis (133). The infections that constitute major causes of illness, hospitalizations, and deaths worldwide are salmonellosis, campylobacteriosis, and Shiga toxin- producing Escherichia coli (STEC). However, despite listeriosis having a lower incidence, it is one of the most lethal foodborne diseases, with an associated mortality rate of $37 \%$ (136).

Within this context, there is an urgent need to find new, rapid, and highly sensitive methods for detecting foodborne pathogenic bacteria. Conventional methods depending on cell culture can take several days to yield results; therefore, interesting alternatives include PCR, ELISA, surface plasmon resonance (SPR), and electrochemical impedance spectroscopy (EIS). Even though these alternatives can be more specific, more sensitive, and faster, they can also be more expensive in terms of instrumentation, involve tedious processes, or require highly qualified personnel for handling (137). For this reason, many efforts have focused on the search for inexpensive, rapid, and robust biosensors for the detection of foodborne pathogenic bacteria. This section presents the latest trends in this area.

\subsection{Enterococcus faecalis}

Enterococci spp. are Gram-positive cocci that can survive in harsh conditions and dramatically expand in healthy individuals under certain conditions $(138,139)$. However, "from the enterococcal species, only Enterococcus faecalis and Enterococcus faecium commonly colonize and infect humans in detectable numbers" (140). Associated infections may include bacteremia, bacterial meningitis, urinary tract infections, endocarditis, and wound infections, among others $(141,142)$. Additionally, Enterococci spp. can produce biogenic amines that serve as a reservoir for virulence and can cause food intoxication $(143,144)$. E. faecalis and $E$. faecium are the most commonly found strains in foods and are associated with human infection (145).

Considering the high prevalence of linfections, the difficulties involved in their effective diagnosis, and the limited available biosensors for their detection, an alternative method for detecting $E$. faecalis infections could represent an improvement in clinical diagnostics and therapy (146-151). Therefore, Nazari-Vanani et al., fabricated a new, PCR-free, label-free, and electrochemical E. faecalis DNA biosensor (Ef-biosensor) to quantify the bacterium genome (152). The design of the Ef-biosensor platform was based on the autonomous selfassembly process at the molecular level, which allows spontaneously rearranging components into ordered patterns $(153,154)$. The objective was to obtain an immobilized, self-assembled, and aligned 
monolayer of the ssDNA probe to work as the detection platform for $E$. faecalis. Some advantages include the easy formation of stable self-assembled monolayers (SAMs) and reduction in the amount of biomolecule immobilized in the transducer (155). The main components of SAMs are 1) a head group that strongly binds to a substrate, 2) a spacer chain responsible for the SAM's thickness and the flexibility of the immobilized species, and 3) a free end functional group that remains available for any modifications (152).

Thiol-gold binding systems have been widely employed to fabricate biosensors and are commonly used for SAM formation due to the strength of the bond, inertness, biocompatibility, and easy formation (156). Because open-circuit potential values during thiol self-assembly remain within the range of gold stability (157), self-assembled monolayers of thiols are formed without requiring the application of an external potential. Therefore, a gold disk electrode was used to immobilize the ssDNA probe. The immobilization time was optimized to seven hours, corresponding to a high concentration of the ssDNA probe on the gold electrode surface, conferring enhanced sensitivity (152). A ferricyanide/ ferrocyanide mixed solution containing $\mathrm{KCl}$ and $\mathrm{K}_{3} \mathrm{Fe}(\mathrm{CN})_{6} / \mathrm{K}_{4} \mathrm{Fe}(\mathrm{CN})_{6}(1: 1)$ was employed as a redox marker, which allowed monitoring the detection process through differential pulse voltammetry (DPV). Different concentrations of the synthetic ssDNA target were plotted against recorded DPVs, observing that the values of DVP decreased when the concentration of the target ssDNA increased. The obtained correlation coefficient was $R^{2}=0.9977$ in a concentration range of $1.0 \times 10^{-17}$ to $1.0 \times 10^{-12}$ mol $\mathrm{L}^{-1}$ for the target ssDNA, and the calculated LOD was $3.3 \mathrm{~mol} \mathrm{~L}^{-1}$ (152).

Regarding the performance characteristics, first, the fabrication reproducibility was demonstrated by manufacturing the Ef-biosensor five times, recording the DPVs for each Ef-biosensor, and obtaining a relative standard deviation (RSD) of 2.8\%. Second, the regeneration ability of the Efbiosensor was investigated by performing five cycles of hybridization/de-hybridization, recording DPVs, and obtaining an RSD of 5.1\% (152). And third, the selectivity was challenged by measuring DPVs after exposure to sequences with one to three base mismatches or non-complementary sequences at the same concentration as the target sequence. The sharpest DPV decrease was observed when the Ef-biosensor hybridized with the ssDNA target sequence, and the smallest decrease was obtained with the non-complementary ssDNA sequence. Considering the inverse relationship between the concentration of the target ssDNA sequence and DPV, the biosensor displayed high selectivity and could discriminate among the mismatched sequences (152).

Moreover, the ability of the Ef-biosensor to quantify the genomic DNA was explored by recording DPVs before and after hybridization with different concentrations of the $E$. faecalis genome. The inverse dependency was still observed between the $E$. faecalis genome concentration and DPV values. The calibration curve had a regression coefficient of $R^{2}=$ 0.9912 in a concentration range of $1.1 \times 10^{-7}$ to $1.1 \mathrm{ng}$ $\mathrm{mL}^{-1}$, and the calculated LOD was $7.1 \times 10^{-9} \mathrm{ng} \mathrm{mL}^{-1}$. Finally, the authors determined that the calculated LOD for both the synthetic and the genomic DNA was very low as compared with other methods of $E$. faecalis detection (152). The Ef-biosensor was successfully applied for E. faecalis detection in human samples. Genomic DNA was extracted from urine, stool, and abdomen de-identified samples discarded from routine clinical practice. PCR amplification followed by gel electrophoresis confirmed the presence of bacterial genome in the real samples, demonstrating the exactitude of the results obtained by the Ef-biosensor (152).

Even though the previously-mentioned biosensors for nucleic acid detection exhibit excellent performance characteristics, other reported biosensors have included an amplification module in order to optimize the detection. Target amplification refers to any method that directly increases the number of copies of target molecules, while signal amplification uses highly sensitive probes to detect the target molecule, directly increasing the signal without increasing the amount of the target (158). PCR was the first nucleic acid amplification method developed. However, a major opportunity for improvement lies in the complex requirements of PCR for thermal cycling, high equipment cost, and elevated time consumption (158-160). Alternative methods have emerged, exploiting the use of isothermal conditions (158-160). The following biosensors that will be discussed have an included amplification module.

\subsection{Group B Streptococci}

In 2015, Yuan et al., (161) developed an electrochemical biosensor for ultrasensitive and specific detection of nucleic acids by combining a defective $T$ junction induced transcription amplification (DTITA), as 
shown in Figure 7. Primer extension reaction and in vitro transcription amplification were triggered to produce numerous single-stranded RNA. These RNA products of DTITA could further hybridize with the detection probes and immobilize capture probes for enzyme-amplified electrochemical detection on the biosensor's surface (161).

Defective T Junction Induced Transcription Amplification

(DTITA).

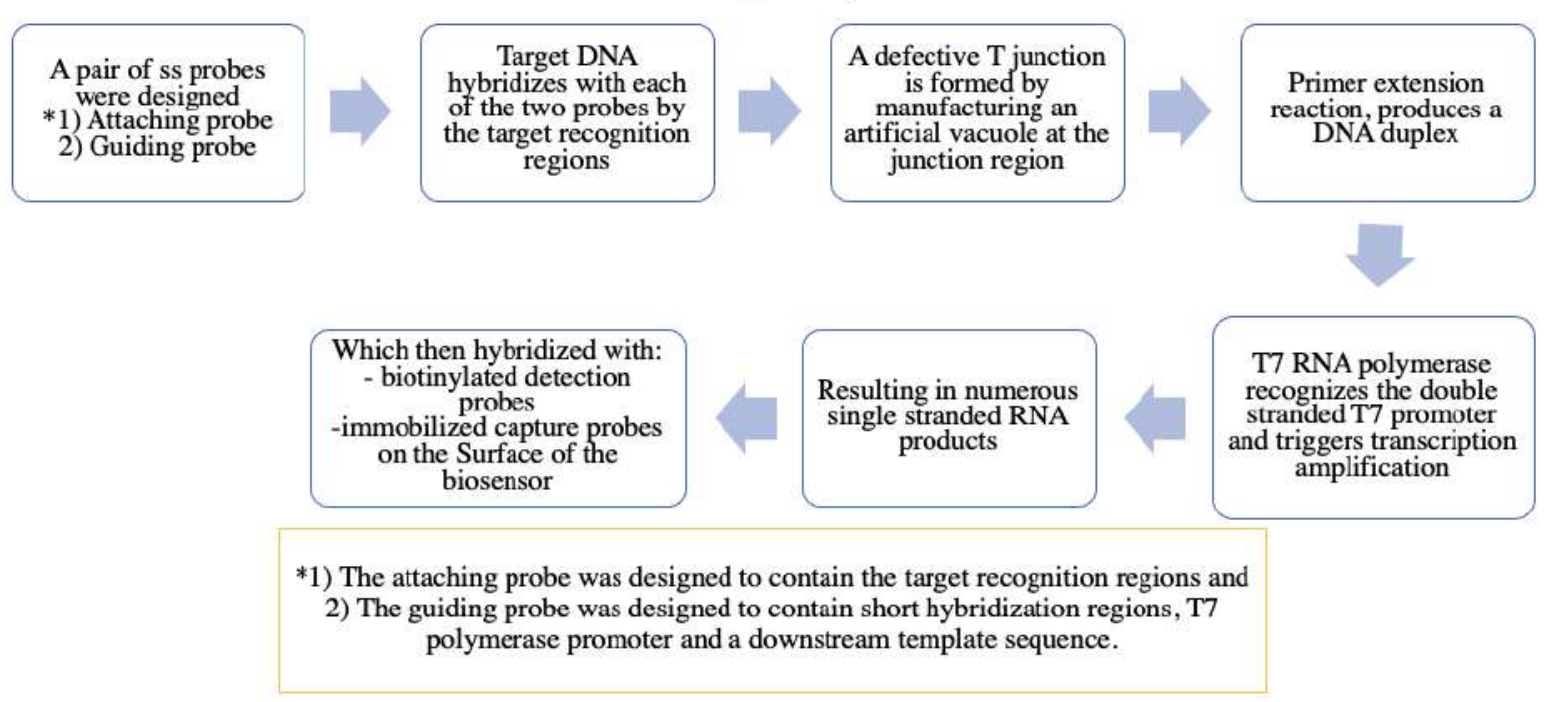

Figure 7. Defective T junction induced transcription amplification (DTITA). (Adapted from (161).

In terms of performance characteristics, the isothermal DTITA strategy displayed remarkable signal amplification performance and reproducibility. The biosensor showed a very high sensitivity for target DNA, with a LOD of $0.4 \mathrm{fM}$, as low as 400 copies of genomic DNA, and a linear range of $1 \mathrm{fM}$ to $1 \mathrm{nM}$. Moreover, the established biosensor was successfully verified for directly identifying Group B Streptococci in clinical samples (161).

\subsection{Salmonella typhimurium}

In 2016, Yan et al., (162) developed an electrochemical biosensing strategy for ultrasensitive and specific detection of pathogenic nucleic acids by directly integrating homogeneous target-initiated transcription amplification (HTITA) with an interfacial sensing process in a single-analysis system, as shown in Figure 8. The HTITA amplification strategy resulted in numerous single-stranded RNA products, which could synchronously hybridize with the detection probes and immobilized capture probes for enzyme-amplified electrochemical detection on the biosensor surface. 
Homogeneous Target-initiated Transcription Amplification (HTITA)
Each DNA duplex contains:

- a T7 promoter

- a downstream transcription template

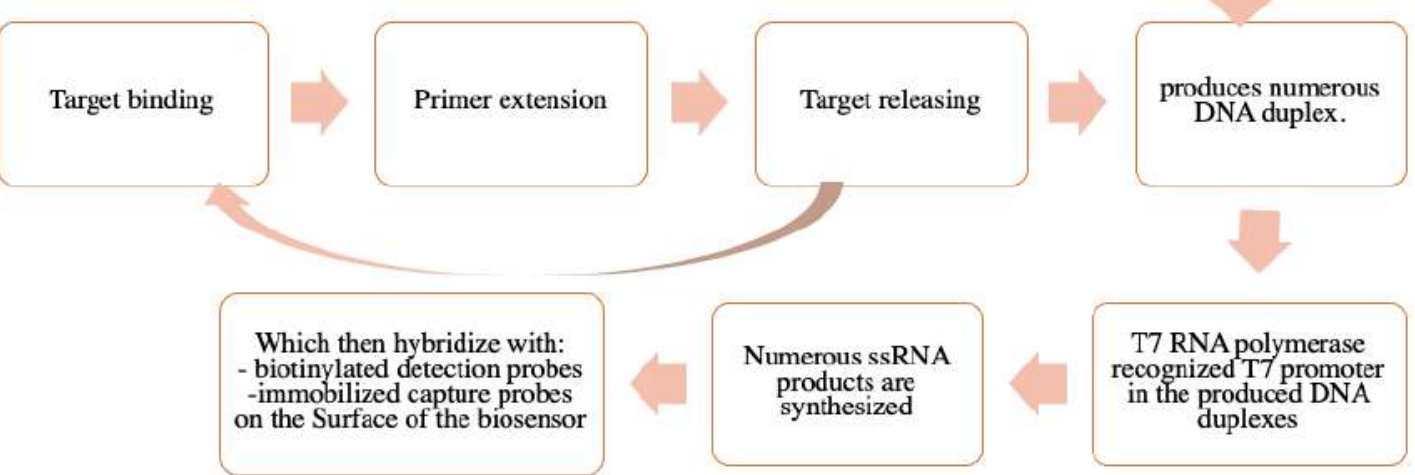

Figure 8. Diagram of homogeneous target-initiated transcription amplification (HTITA). (Adapted from (162).

The proposed electrochemical biosensing strategy showed very high sensitivity and selectivity for target DNA, with a dynamic response range from $1 \mathrm{fM}$ to $100 \mathrm{pM}$ and a calculated LOD of $0.97 \mathrm{fM}$. Using Salmonella typhimurium as a model, the established strategy was successfully applied to directly detect the invA gene from genomic DNA extract (162).

Alternatively, Shasha Li et al., (135) reported a new technique for detecting pathogenic bacteria, using the isothermal circular strand displacement polymerization strategy (ICSDP). This technique involves a polymerization reaction of a specific primer with a single-stranded template in the presence of polymerase. The target can be replaced by a second target during polymerization, which promotes more polymerization cycles and amplifies the detection. Even though ICSDP has been widely used to detect various analytes such as nucleic acids, proteins, small molecules, and toxic metals, this is the first report of bacterial detection (163-166).

The working principle of the novel ICSDP developed for bacterial detection is described in Figure 4. The technique is made up of five elements: (i) the arched probe, used for the specific recognition of the target analyte, in this case, Salmonella typhimurium, (ii) a hairpin probe 1 (HAP-1) that functions as a template, (iii) a fluorescence-quenched hairpin probe 2 (HAP-2) that functions as a pre-primer and is the fluorescent signal indicator, (iv) DNA-polymerase enzymes (Phi-29), and (v) an endonuclease (Nt.Alwl), involved in the amplification cycles. The arched probe comprises an anti-S typhimurium aptamer, which is carefully designed to specifically recognize the bacteria and release the $T$ trigger (Figure 9. Step 1). The T trigger recognizes the $5^{\prime}$ terminal region of HAP-1, which has a $T$ * sequence, which generates a change in its three-dimensional structure, and its $3^{\prime}$ terminal region is exposed (Figure 9, Step 2). This region will specifically recognize the $S$ region of HAP-2, which will again change its three-dimensional conformation to leave the $L$ tail exposed and unpaired (Figure 9, Steps 3-4). This tail is digested by the enzyme phi 29; meanwhile, the Dabcyl fluorophore present in the L tail is released, and the detectable fluorescent signal is generated (Figure 9, Step 5). Finally, the enzyme Nt.Alwl breaks the pairing of the $T$ trigger with HAP-1, leaving the $T$ sequence free to repeat the cycle (Figure 9, Step 8). 


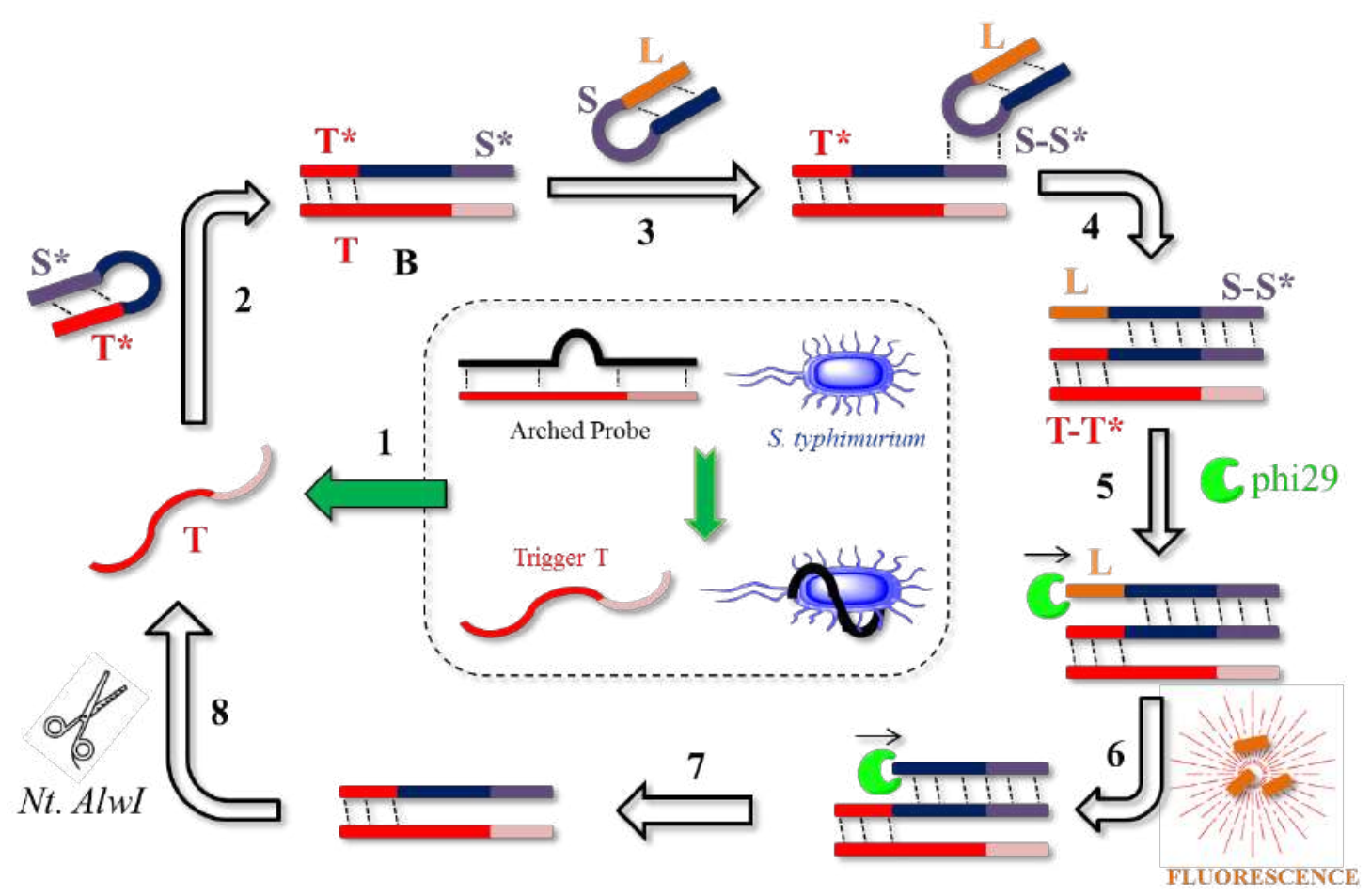

Figure 9. General scheme of ICSDP-type biosensor for the detection of foodborne pathogenic bacteria. (Adapted from (135).

The developed ICSDP strategy constitutes a robust detection method with shorter analysis times than conventional techniques and a simplified operation involving single reaction step. The method is highly sensitive, with a LOD below 1.5 CFU $\mathrm{mL}^{-1}$, and it is specific for $S$. typhimurium in the presence of different bacteria such as B. subtilis, Listeria, and $E$. coli, having fluorescence intensity values close to 1000 a.u for $S$. typhimurium and values less than 100 a.u. for the other bacteria under the same conditions. Finally, the authors challenged the method with complex milk matrices, demonstrating competitive efficiency with recovery percentages between $98 \%$ and $109 \%$, similar to conventional methods based on counting and cell culture (135).

\subsection{Salmonella enteritis and Staphylococcus aureus}

Fluorescence biosensors, such as SPR and surfaceenhanced Raman scattering (SERPS) biosensors, have different action principles. Still, most of them share the same working pattern: (i) capture of the analyte, (ii) separation, (iii) flushing, and (iv) amplification and detection of the signal. These processes involve two major challenges for the development of bacterial biosensors. On the one hand, bacteria tend to be present in complex matrices, so they must be captured, separated, labeled, and rinsed before being detected, which involves tedious sample treatment processes. At the same time, given the low concentrations of the bacteria in food samples, biosensors must be highly sensitive. The latter could be achieved with high surface areas that enable efficient biosensor-analyte interaction (167).

To face these challenges, Chen et al., (167) proposed a multi-channel structured 3D chip made up of an organic polymer of polymethyl methacrylate (PMMA) cut in the shape of a disk (Figure 10) (166). Given its high porosity, generated during the polymerization processes, the 3D chip has a high surface area, which facilitates mass transfer, offers many active sites, has good flexibility for the optical path of light, and simplifies the analytical process. The active sites of the 3D chip were occupied with an aptamer specifically designed to recognize a particular bacterium (Figure 10A). A complex sample is forced to flow through the disk, where the aptamer selectively captures the bacteria, and the other analytes are eluted (Figure 10B). Finally, through a strategy known as hybridization chain reaction (HCR), the signal of the immobilized bacterium is amplified in order to obtain a fluorescent signal, which is similar to the strategy proposed by Shasha Li et al., in 2019 (Figure 10C) (135,167). 


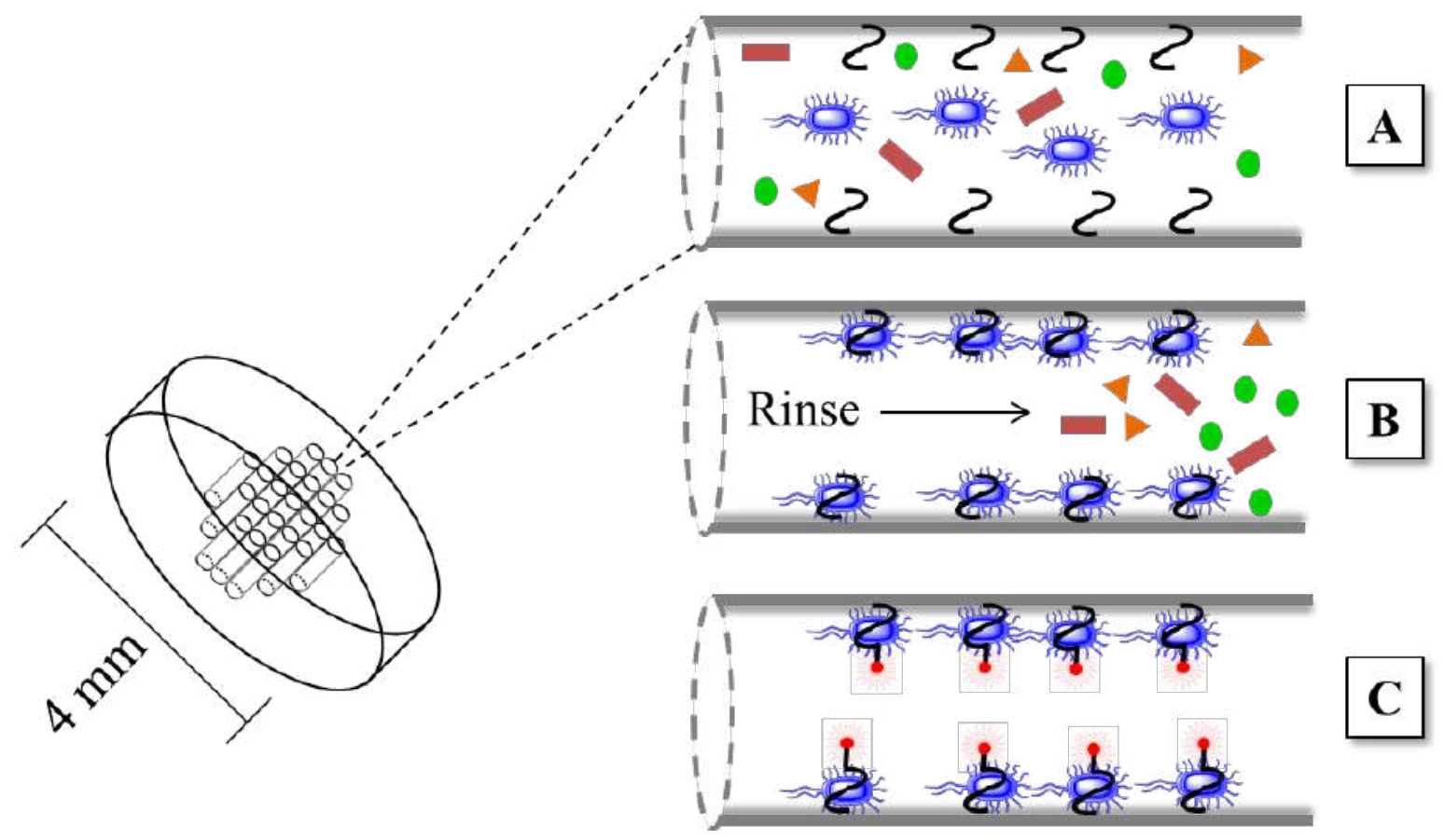

Figure 10. Multi-channel structured 3D chip for the detection of foodborne pathogenic bacteria. (Adapted from (167).

The 3D multichannel chip biosensor is fast (15-minute analysis), inexpensive, and does not require multiple reaction steps. The designed biosensor efficiently detected two bacterial models: Salmonella enteritis and Staphylococcus aureus, reaching a LOD below $4 \mathrm{CFU} \mathrm{mL} \mathrm{m}^{-1}$ and a wide linear range that oscillates

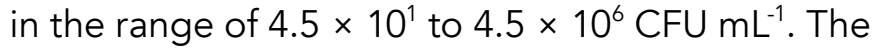
3D chip model opens new possibilities since it could be scaled to other optical detection strategies (167).

\subsection{Microcystin-LR}

Not only bacteria pose food contamination problems: also, the toxins they produce can lead to serious diseases, mainly because they remain in food and water at low concentrations. For example, cyanobacteria produce a group of biologically active toxins called microcystins, posing a serious threat to aquatic organisms and human health. Microcystin-LR (MC-LR) is the most common and dangerous ones in the group. It has been reported that exposure to low concentrations of MC-LR may be associated with the development of tumors, liver cancer, and chronic diseases. The $\mathrm{WHO}$ recommends a concentration of less than $1 \mu \mathrm{g} \mathrm{mL}^{-1}$ of MC-LR in water. Thus there is an urgent need to develop highly sensitive and precise biosensors that will allow reliable detection of MC-LR at low concentrations (168).

Wu et al., (168) reported a novel biosensor that could be extrapolated to other similar analytes (Figure 11). It is made up of two strands (A and B) chemically bonded to a polyacrylamide polymer. Subsequently, these strands are joined together by an MC-LR aptamer that generates a hydrogel in which the aptamer will function as a crosslinking agent. Cu/Au/ Pt nanoparticles are encapsulated within this DNAhydrogel. Upon contact with the MC-LR analyte, the aptamer specifically binds to the target, forming a target-aptamer complex that disintegrates the membrane, releasing the metallic nanoparticles. The free metallic nanoparticles catalyze the reaction between TMB (Tetramethylbenzidine) and $\mathrm{H}_{2} \mathrm{O}_{2}$, thus generating a strong blue coloration that can be monitored using colorimetric techniques (168). 


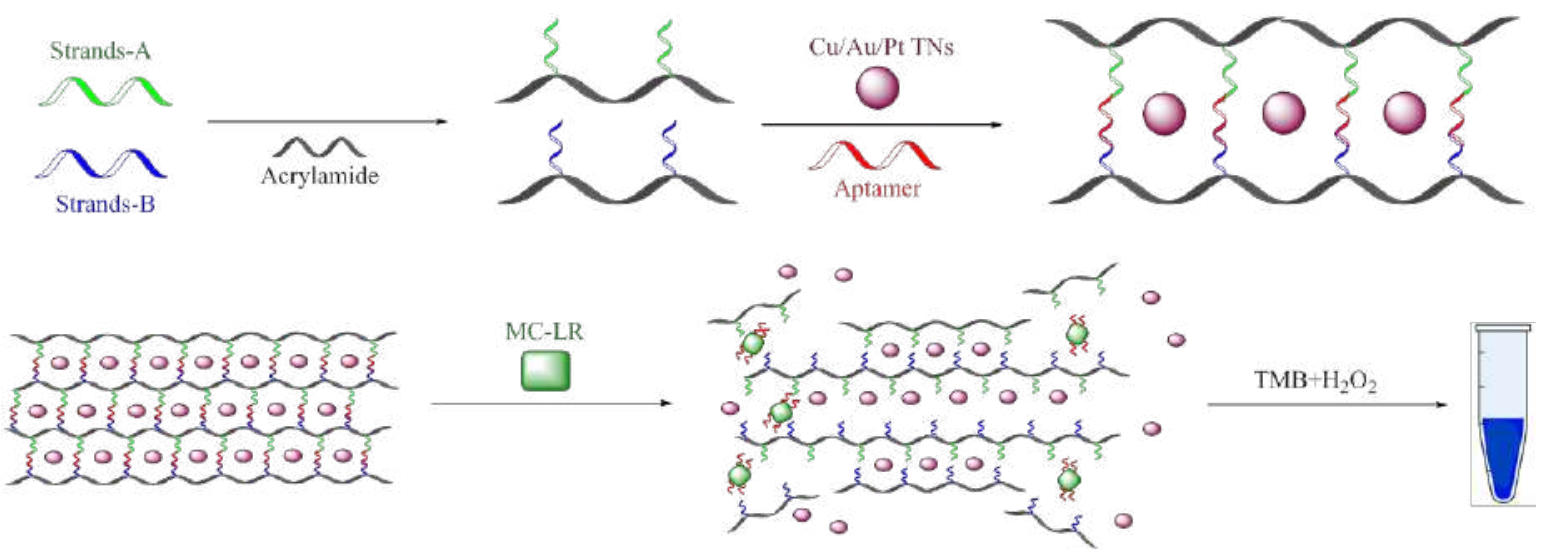

Figure 11. General DNA-hydrogel scheme for the detection of MC-LR. (Adapted from (168).

The authors demonstrated that this biosensor is reliable and feasible: it was tested fresh fish and spiked water samples, yielding recovery percentages between $95 \%$ and $107 \%$ and RSD lower than $5 \%$. Additionally, the results obtained with this biosensor were consistent compared to the ELISA kit. A linear range of $0.004-10 \mu \mathrm{g} \mathrm{L}^{-1}$ and a LOD of $3.0 \mathrm{ng} \mathrm{L}^{-1}$ were reported, exhibiting values much lower than those reported for other analytical techniques for the detection of MC-LR: chemiluminescence, using the antibody-antigen model (169), electrochemical, using 3D graphene electrodes (170), or fluorescence, using Eu nanospheres, among others (168).

A comprehensive summary of the performance characteristics of the discussed biosensors is shown in Table 2.

Table 2. Summary of performance characteristics for the discussed biosensors for detection of foodborne pathogenic agents.

\begin{tabular}{|c|c|c|c|c|c|c|c|}
\hline Authors & $\begin{array}{c}\text { Biorecognition } \\
\text { element }\end{array}$ & Analyte & Transducer & LOD & Linear range & Real Samples & $\begin{array}{c}\text { Amplification } \\
\text { Strategy }\end{array}$ \\
\hline $\begin{array}{l}\text { Nazari- } \\
\text { Vanani et } \\
\text { al., } 2019\end{array}$ & ssDNA & $\begin{array}{l}\text { Synthetic DNA of } \\
\text { E. faecalis }\end{array}$ & Gold electrode & $3.3 \mathrm{amol} \mathrm{L}{ }^{-1}$ & $\begin{array}{l}1.0 \times 10^{-17} \text { to } 1.0 \\
\times 10^{-12} \mathrm{~mol} \mathrm{~L}^{-1}\end{array}$ & $\begin{array}{l}\text { Genomic DNA } \\
\text { LOD: } 7.1 \times 10^{-9} \mathrm{ng} \mathrm{mL}^{-1} \\
\text { Linear range: } 1.1 \times 10^{-7} \\
\text { to } 1.1 \mathrm{ng} \mathrm{mL}^{-1}\end{array}$ & N.A \\
\hline $\begin{array}{l}\text { Yuan et al., } \\
2015\end{array}$ & Aptamer & $\begin{array}{l}\text { Synthetic DNA } \\
\text { of Group B } \\
\text { Streptococci }\end{array}$ & Gold electrode & $0.4 \mathrm{fM}$ & $1 \mathrm{fM}$ to $1 \mathrm{nM}$ & $\begin{array}{l}\text { Genomic DNA from } \\
\text { clinical vaginal/anal } \\
\text { samples } \\
\end{array}$ & DTITA \\
\hline $\begin{array}{l}\text { Yan et al., } \\
2016 .\end{array}$ & Aptamer hairpin & $\begin{array}{l}\text { Salmonella } \\
\text { typhimurium }\end{array}$ & Gold electrode & $0.97 \mathrm{fM}$ & $1 \mathrm{fM}$ to $100 \mathrm{pM}$. & $\begin{array}{l}\text { LOD: } 10^{5} \mathrm{CFU} \mathrm{mL}^{-1} \\
\text { Linear range: } 10-10^{7} \\
\text { CFU mL }\end{array}$ & HTITA \\
\hline $\begin{array}{l}\text { Shasha } \\
\text { Li et al., } \\
2019\end{array}$ & $\begin{array}{l}\text { Arched probe } \\
\text { aptamer, HAP-1, } \\
\text { HAP-2 }\end{array}$ & $\begin{array}{l}\text { Salmonella } \\
\text { typhimurium }\end{array}$ & Fluorescence & 1.5 CFU mL $\mathrm{m}^{-1}$ & 1000 a.u & Milk 98-109\% & ICSDP \\
\hline $\begin{array}{l}\text { Chen et } \\
\text { al., } 2014\end{array}$ & 3D chip-PMMA & $\begin{array}{l}\text { Salmonella enteritis } \\
\text { and Staphylococcus } \\
\text { aureus }\end{array}$ & Fluorescence & $4 \mathrm{CFU} \mathrm{mL} \mathrm{m}^{-1}$ & $\begin{array}{l}4.5 \times 10^{1} \text { to } 4.5 \\
\times 10^{6} \mathrm{CFU} \mathrm{mL}^{-1} .\end{array}$ & N. A. & $\mathrm{HCR}$ \\
\hline $\begin{array}{l}\text { Wu et al., } \\
2020\end{array}$ & $\begin{array}{l}\text { Polyacrylamide } \\
\text { hydrogel: } \\
\text { aptamer strands }\end{array}$ & MC-LR & Colorimetric & $3.0 \mathrm{ngL}^{-1}$ & 0.004 to $10 \mu \mathrm{gL}^{-1}$ & $\begin{array}{l}\text { Fresh fish } \\
\text { \%Recovery: 95-107 }\end{array}$ & N.A \\
\hline
\end{tabular}

DTITA: defective T junction induced transcription amplification; HTITA: homogeneous target-initiated transcription amplification; ICSDP: isothermal circular strand displacement polymerization; HAP-1: Hairpin Probe 1; HAP-2: fluorescence-quenched hairpin probe 2; Phi-29: DNA-polymerase enzymes; Nt.Alwl: endonuclease; PMMA: polymethyl methacrylate; MC-LR: Microcystin-LR. 
In addition to the discussed novel applications of nucleic acid-based biosensors in food safety, it is important to emphasize several other reports that may be older but strengthen the importance of biosensing techniques in food quality monitoring. Escherichia coli is a bioindicator of fecal contamination in food and has been detected using potentiometric biosensors (171-173). The screening of food sweeteners through biosensors has been explored because of their association with dental caries, cardiovascular diseases, obesity, and type-2 diabetes (43). Commercially available biosensors have important applications in the fermentation industry because of their potential for online monitoring of critical metabolites that need to be controlled and optimized in the biological processes. Biosensors for detecting and quantifying biochemical parameters such as glucose, lactate, lysine, and ethanol, among others, have been reported (174). Glutamine deficit has been associated with pathologies such as malabsorptive disorders; therefore, requirements for supplementation have been increasing (175). An amperometric biosensor for detecting glucose, glutamate, and glutamine in cell-culture fermentation processes has been reported (176). The aging of beer has been monitored using enzymatic biosensors based on cobalt phthalocyanine (177). Biosensing techniques have also been reported to quantify organophosphates in milk (178) and carbamic and organophosphates in water, orange juice, and wine samples (179-181).

\section{CONCLUSIONS AND FUTURE PERSPECTIVES}

This review compiles research aimed at the design and development of biosensors to detect analytes in complex matrices. There is evidence of notable progress in the identification and/or quantification of analytes in biological and environmental samples with selectivity, specificity, and low detection limits. However, there is an urgent necessity to make progress in developing biosensors that can be used in situ, maintaining or improving the analytical properties achieved in the design phase.

Biosensors as medical devices have proved valuable and promising tools for mitigating morbidity and mortality caused by high-impact diseases. Biosensors have been used for the early diagnosis of diseases, identification of biomarkers, monitoring of the evolution of pathologies during treatment and as drug delivery systems. The greatest challenge in designing biosensors for disease diagnosis is identifying the bioreceptor-analyte pair that allows selectivity, specificity, and sensitivity to ensure the absence of false positives.

Aptamers are excellent biorecognition elements, with advantages such as (i) versatility, because they can be used for the identification of cells, proteins, nucleic acids, metabolites, pathogens, drugs, enantiomers, etc. (ii) they have both high affinity and specific binding to the target, due to their three-dimensional conformation, (ii) the ability to hybridization allows the dual function of immobilization to the support and interaction with the analyte, (iii) reproducibility, stability over time and low costs.

Despite the great progress that has been made in developing analytical methods to monitor the presence of pathogens or toxins in the food chain (food production, storage, transport, and marketing), biosensors are urgently needed to ensure food safety.

\section{CONFLICT OF INTEREST}

The authors declare no conflict of interest.

\section{ACKNOWLEDGEMENTS}

This research was conducted with the financial support of the Instituto Nacional de Metrología (INM) and Universidad Nacional de Colombia (Project code 201010023779). The authors wish to thank Samadhi Ustariz and Karla Rodríguez for their collaboration throughout the literature review.

\section{REFERENCES}

1. Kumar H, Kumari N, Sharma R. Nanocomposites (conducting polymer and nanoparticles) based electrochemical biosensor for the detection of environment pollutant: Its issues and challenges. Environ Impact Assess Rev 2020;85:106438. https:// doi.org/10.1016/j.eiar.2020.106438.

2. Chang K, Deng S, Chen M. Novel biosensing methodologies for improving the detection of single nucleotide polymorphism. Biosens Bioelectron 2015;66:297-307. https://doi.org/10.1016/j. bios.2014.11.041.

3. Malhotra BD, Ali MA. Nanomaterials in Biosensors. Nanomater. Biosens., Elsevier; 2018, p. 1-74. https://doi.org/10.1016/B9780-323-44923-6.00001-7.

4. Bhalla N, Jolly P, Formisano N, Estrela P. Introduction to biosensors. Essays Biochem 2016;60:1-8. https://doi.org/10.1042/ EBC20150001.

5. Karunakaran C, Rajkumar R, Bhargava K. Introduction to Biosensors. Elsevier Inc.; 2015. https://doi.org/10.1016/B978-012-803100-1.00001-3. 
6. Ensafi AA. An introduction to sensors and biosensors. Elsevier Inc.; 2019. https://doi.org/10.1016/B978-0-12-816491-4.00001-2.

7. Davis F, Altintas Z. General Introduction to Biosensors and Recognition Receptors. Biosens. Nanotechnol., Hoboken, NJ, USA: John Wiley \& Sons, Inc.; 2017, p. 1-15. https://doi. org/10.1002/9781119065036.ch1.

8. Parmin NA, Hashim U, Gopinath SCB, Uda MNA. Biosensor recognizes the receptor molecules. Elsevier Inc.; 2018. https:// doi.org/10.1016/B978-0-12-813900-4.00008-7.

9. Xiong $E$, Zhen $D$, Jiang L. Homogeneous enzyme-free and entropy-driven isothermal fluorescent assay for nucleic acids based on a dual-signal output amplification strategy. Chem Commun 2018;54:12594-7. https://doi.org/10.1039/C8CC07508E.

10. Kosack CS, Page AL, Klatser PR. A guide to aid the selection of diagnostic tests. Bull World Health Organ 2017;95:639-45. https://doi.org/10.2471/BLT.16.187468.

11. Moccia M, Caratelli V, Cinti S, Pede B, Avitabile C, Saviano $M$, et al. Paper-based electrochemical peptide nucleic acid (PNA) biosensor for detection of miRNA-492: a pancreatic ductal adenocarcinoma biomarker. Biosens Bioelectron 2020;165:112371. https://doi.org/10.1016/j.bios.2020.112371

12. Hu Q, Wang $Q$, Sun G, Kong J, Zhang X. Electrochemically Mediated Surface-Initiated de Novo Growth of Polymers for Amplified Electrochemical Detection of DNA. Anal Chem 2017;89:9253-9. https://doi.org/10.1021/acs.analchem.7b02039.

13. Wang C, Liu J, Kong J, Zhang X. Nitronyl nitroxide monoradical TEMPO as new electrochemical label for ultrasensitive detection of nucleic acids. Anal Chim Acta 2020;1136:19-24. https://doi. org/10.1016/j.aca.2020.08.035.

14. Luo Y. Functional Nucleic Acid Based Biosensors for Food Safety Detection. 2018. https://doi.org/10.1007/978-981-10-8219-1.

15. Ribeiro BV, Cordeiro TAR, Oliveira e Freitas GR, Ferreira LF, Franco DL. Biosensors for the detection of respiratory viruses: $A$ review. Talanta Open 2020;2:100007. https://doi.org/10.1016/j. talo.2020.100007.

16. Sergeev N V., Herold KE, Rasooly A. Regulatory and Validation Issues for Biosensors and Related Bioanalytical Technologies. Handb. Biosens. Biochips, Chichester, UK: John Wiley \& Sons, Ltd; 2008. https://doi.org/10.1002/9780470061565.hbb132.

17. Migliozzi D, Guibentif T. Assessing the potential deployment of biosensors for point-of-care diagnostics in developing countries: Technological, economic and regulatory aspects. Biosensors 2018;8. https://doi.org/10.3390/bios8040119.

18. Clark LC, Lyons C. Electrode Systems for Continuous Monitoring in Cardiovascular Surgery. Ann N Y Acad Sci 1962;102:29-45. https://doi.org/10.1111/j.1749-6632.1962.tb13623.x.

19. Davis F, Higson SPJ. Structured thin films as functional components within biosensors. Biosens Bioelectron 2005;21:1-20. https://doi. org/10.1016/j.bios.2004.10.001

20. Díaz-González M, González-García MB Costa-García A Recent Advances in Electrochemical Enzyme Immunoassays. Electroanalysis 2005;17:1901-18. https://doi.org/10.1002/ elan.200503357.

21. Rodriguez-Mozaz S, Lopez de Alda MJ, Barceló D. Biosensors as useful tools for environmental analysis and monitoring. Anal Bioanal Chem 2006;386:1025-41. https://doi.org/10.1007/ s00216-006-0574-3.

22. Scognamiglio V, Pezzotti G, Pezzotti I, Cano J, Buonasera K, Giannini D, et al. Biosensors for effective environmental and agrifood protection and commercialization: From research to market. Microchim Acta 2010;170:215-25. https://doi. org/10.1007/s00604-010-0313-5.
23. Li J, Stachowski M, Zhang Z. Application of responsive polymers in implantable medical devices and biosensors. Switch. Responsive Surfaces Mater. Biomed. Appl., Elsevier Inc.; 2015, p. 259-98. https://doi.org/10.1016/B978-0-85709-713-2.00011-0.

24. Vasala A, Hytönen VP, Laitinen OH. Modern Tools for Rapid Diagnostics of Antimicrobial Resistance. Front Cell Infect Microbiol 2020;10. https://doi.org/10.3389/fcimb.2020.00308.

25. Ahmed A, Rushworth J V., Hirst NA, Millner PA. Biosensors for whole-cell bacterial detection. Clin Microbiol Rev 2014;27:63146. https://doi.org/10.1128/CMR.00120-13.

26. Habli Z, Alchamaa W, Saab R, Kadara H, Khraiche ML. Circulating tumor cell detection technologies and clinical utility: Challenges and opportunities. Cancers (Basel) 2020;12:1-30. https://doi. org/10.3390/cancers12071930.

27. Wibowo KM, Muslihati A, Sahdan MZ, Rosni NM, Basri H, Fudholi A. A novel, portable Escherichia coli bacteria sensor using graphene as sensing material. Mater Chem Phys 2020;254:123459. https://doi.org/10.1016/j.matchemphys.2020.123459.

28. Guo J, Liu D, Yang Z, Weng W, Chan EWC, Zeng Z, et al. A photoelectrochemical biosensor for rapid and ultrasensitive norovirus detection. Bioelectrochemistry 2020;136:107591. https://doi.org/10.1016/j.bioelechem.2020.107591.

29. Vermisoglou E, Panáček D, Jayaramulu K, Pykal M, Frébort I, Kolář $\mathrm{M}$, et al. Human virus detection with graphene-based materials. Biosens Bioelectron 2020;166:112436. https://doi.org/10.1016/j. bios.2020.112436.

30. Sá SR, Silva Junior AG, Lima-Neto RG, Andrade CAS, Oliveira MDL. Lectin-based impedimetric biosensor for differentiation of pathogenic candida species. Talanta 2020;220:121375. https:// doi.org/10.1016/j.talanta.2020.121375.

31. Deepa, Pundir S, Pundir CS. Detection of tumor suppressor protein p53 with special emphasis on biosensors: A review. Anal Biochem 2020;588:113473. https://doi.org/10.1016/j. ab.2019.113473.

32. Hou L, Huang Y, Hou W, Yan Y, Liu J, Xia N. Modification-free amperometric biosensor for the detection of wild-type p53 protein based on the in situ formation of silver nanoparticle networks for signal amplification. Int J Biol Macromol 2020;158:580-6. https:// doi.org/10.1016/j.ijbiomac.2020.04.271.

33. Ameri M, Shabaninejad Z, Movahedpour A, Sahebkar A, Mohammadi S, Hosseindoost $S$, et al. Biosensors for detection of Tau protein as an Alzheimer's disease marker. Int J Biol Macromol 2020;162:1100-8. https://doi.org/10.1016/j.ijbiomac.2020.06.239.

34. Sohrabi H, kholafazad Kordasht H, Pashazadeh-Panahi P, NezhadMokhtari P, Hashemzaei M, Majidi MR, et al. Recent advances of electrochemical and optical biosensors for detection of $\mathrm{C}$-reactive protein as a major inflammatory biomarker. Microchem J 2020;158:105287. https://doi.org/10.1016/j.microc.2020.105287.

35. Sars-cov- S, Mavrikou S, Moschopoulou G, Tsekouras V. Protein Antigen 2020.

36. Samson R, Navale GR, Dharne MS. Biosensors: frontiers in rapid detection of COVID-19. 3 Biotech 2020;10:385. https://doi. org/10.1007/s13205-020-02369-0.

37. Xing $Y, X i a ~ N$. Biosensors for the Determination of Amyloid-Beta Peptides and their Aggregates with Application to Alzheimer's Disease. Anal Lett 2015;48:879-93. https://doi.org/10.1080/000 32719.2014.968925.

38. Boschetti E, D'Amato A, Candiano G, Righetti PG. Protein biomarkers for early detection of diseases: The decisive contribution of combinatorial peptide ligand libraries. J Proteomics 2018;188:1-14. https://doi.org/10.1016/j.jprot.2017.08.009. 
39. Li J, Zhu Y, Wu X, Hoffmann MR. Rapid detection methods for bacterial pathogens in ambient waters at the point of sample collection: A brief review. Clin Infect Dis 2020;71:S84-90. https:// doi.org/10.1093/cid/ciaa498.

40. Jiang Y, Qiu Z, Le T, Zou S, Cao X. Developing a dual-RCA microfluidic platform for sensitive $\mathrm{E}$. coli $\mathrm{O} 157: \mathrm{H} 7$ whole-cell detections. Anal Chim Acta 2020;1127:79-88. https://doi. org/10.1016/j.aca.2020.06.046.

41. Farooq U, Ullah MW, Yang Q, Aziz A, Xu J, Zhou L, et al. Highdensity phage particles immobilization in surface-modified bacterial cellulose for ultra-sensitive and selective electrochemical detection of Staphylococcus aureus. Biosens Bioelectron 2020;157:112163. https://doi.org/10.1016/j.bios.2020.112163.

42. Keshavarz A, Zangenehzadeh S, Hatef A. Optimization of surface plasmon resonance-based biosensors for monitoring hemoglobin levels in human blood. Appl Nanosci 2020;10:1465-74. https:// doi.org/10.1007/s13204-020-01252-x.

43. Mehrotra P. Biosensors and their applications - A review. J Oral Biol Craniofacial Res 2016;6:153-9. https://doi.org/10.1016/j. jobcr.2015.12.002.

44. Giuliano KA, Taylor DL. Fluorescent-protein biosensors: New tools for drug discovery. Trends Biotechnol 1998;16:135-40. https:// doi.org/10.1016/S0167-7799(97)01166-9.

45. Wolff M, Wiedenmann J, Nienhaus GU, Valler M, Heilker R. Novel fluorescent proteins for high-content screening. Drug Discov Today 2006;11:1054-60. https://doi.org/10.1016/j. drudis.2006.09.005.

46. Lang P, Yeow K, Nichols A, Scheer A. Cellular imaging in drug discovery. Nat Rev Drug Discov 2006;5:343-56. https://doi. org/10.1038/nrd2008.

47. El-Deiry WS, Sigman CC, Kelloff GJ. Imaging and oncologic drug development. J Clin Oncol 2006;24:3261-73. https://doi. org/10.1200/JCO.2006.06.5623.

48. Willmann JK, van Bruggen N, Dinkelborg LM, Gambhir SS. Molecular imaging in drug development. Nat Rev Drug Discov 2008;7:591-607. https://doi.org/10.1038/nrd2290.

49. Nandimandalam H, Gude VG. Indigenous biosensors for in situ hydrocarbon detection in aquatic environments. Mar Pollut Bull 2019;149:110643. https://doi.org/10.1016/j.marpolbul.2019.110643.

50. Barel-Cohen K, Shore LS, Shemesh M, Wenzel A, Mueller J, Kronfeld-Schor N. Monitoring of natural and synthetic hormones in a polluted river. J Environ Manage 2006;78:16-23. https://doi. org/10.1016/j.jenvman.2005.04.006.

51. Nozaki O. Steroid analysis for medical diagnosis. J Chromatogr A 2001;935:267-78. https://doi.org/10.1016/S0021-9673(01)01104-9.

52. Ying GG, Kookana RS, Ru YJ. Occurrence and fate of hormone steroids in the environment. Environ Int 2002;28:545-51. https:// doi.org/10.1016/S0160-4120(02)00075-2.

53. Wegener HC. Antibiotics in animal feed and their role in resistance development. Curr Opin Microbiol 2003;6:439-45. https://doi. org/10.1016/j.mib.2003.09.009.

54. Sumpter JP, Jobling S. Vitellogenesis as a biomarker for estrogenic contamination of the aquatic environment. Environ. Health Perspect., vol. 103, Public Health Services, US Dept of Health and Human Services; 1995, p. 173-8. https://doi. org/10.1289/ehp.95103s7173.

55. Adrián J, Fernández F, Muriano A, Obregon R, Ramón-Azcon J, Tort N, et al. Biosensors for Pharmaceuticals and Emerging Contaminants Based on Novel Micro and Nanotechnology Approaches. Handb. Environ. Chem. Vol. 5 Water Pollut., vol. 5 J, 2009, p. 47-68. https://doi.org/10.1007/978-3-540-36253-1_3.
56. Lu X, Sun J, Sun X. Recent advances in biosensors for the detection of estrogens in the environment and food. TrAC Trends Anal Chem 2020;127:115882. https://doi.org/10.1016/j. trac.2020.115882.

57. Kim YS, Jung HS, Matsuura T, Lee HY, Kawai T, Gu MB. Electrochemical detection of $17 \beta$-estradiol using DNA aptamer immobilized gold electrode chip. Biosens Bioelectron 2007;22:2525-31. https://doi.org/10.1016/j.bios.2006.10.004.

58. Jo M, Ahn JY, Lee J, Lee S, Hong SW, Yoo JW, et al. Development of single-stranded DNA aptamers for specific bisphenol a detection. Oligonucleotides 2011;21:85-91. https://doi. org/10.1089/oli.2010.0267.

59. Ma Y, Liu J, Li H. Diamond-based electrochemical aptasensor realizing a femtomolar detection limit of bisphenol $A$. Biosens Bioelectron 2017;92:21-5. https://doi.org/10.1016/j. bios. 2017.01.041.

60. Abnous K, Danesh NM, Ramezani M, Alibolandi M, Taghdisi SM. A novel electrochemical sensor for bisphenol A detection based on nontarget-induced extension of aptamer length and formation of a physical barrier. Biosens Bioelectron 2018;119:204-8. https:// doi.org/10.1016/j.bios.2018.08.024.

61. Nameghi MA, Danesh NM, Ramezani M, Alibolandi M, Abnous K, Taghdisi SM. An ultrasensitive electrochemical sensor for $17 \beta$-estradiol using split aptamers. Anal Chim Acta 2019;1065:107-12. https://doi.org/10.1016/j.aca.2019.02.062.

62. Rathnayake IVN, Megharaj M, Naidu R. Green fluorescent protein based whole cell bacterial biosensor for the detection of bioavailable heavy metals in soil environment. Environ Technol Innov 2021;23:101785. https://doi.org/10.1016/j.eti.2021.101785.

63. Tian M, Qiao M, Shen C, Meng F, Frank LA, Krasitskaya V V., et al. Highly-sensitive graphene field effect transistor biosensor using PNA and DNA probes for RNA detection. Appl Surf Sci 2020;527. https://doi.org/10.1016/j.apsusc.2020.146839.

64. Carpenter AC, Paulsen IT, Williams TC. Blueprints for biosensors: Design, limitations, and applications. Genes (Basel) 2018;9. https://doi.org/10.3390/genes9080375.

65. Ozer T, Geiss BJ, Henry CS. Review-Chemical and Biological Sensors for Viral Detection. J Electrochem Soc 2020;167:037523. https://doi.org/10.1149/2.0232003jes.

66. Wu Q, Zhang Y, Yang Q, Yuan N, Zhang W. Review of Electrochemical DNA Biosensors for Detecting Food Borne Pathogens. Sensors 2019;19:4916. https://doi.org/10.3390/s19224916.

67. Palchetti I, Bettazzi F. Nucleic Acid-Based Sensors. Encycl. Interfacial Chem., vol. 80, Elsevier; 2018, p. 392-402. https://doi. org/10.1016/B978-0-12-409547-2.13487-0.

68. Gaudin V. Advances in biosensor development for the screening of antibiotic residues in food products of animal origin - A comprehensive review. Biosens Bioelectron 2017;90:363-77. https://doi.org/10.1016/j.bios.2016.12.005.

69. Yan M, Bai W, Zhu C, Huang Y, Yan J, Chen A. Design of nucleasebased target recycling signal amplification in aptasensors. Biosens Bioelectron 2016;77:613-23. https://doi.org/10.1016/j. bios.2015.10.015.

70. Dembowski SK, Bowser MT. CE-SELEX: Rapid Aptamer Selection Using Capillary Electrophoresis. Sciex 2016:1-10.

71. Kim YS, Kim JH, Kim IA, Lee SJ, Jurng J, Gu MB. A novel colorimetric aptasensor using gold nanoparticle for a highly sensitive and specific detection of oxytetracycline. Biosens Bioelectron 2010;26:1644-9. https://doi.org/10.1016/j.bios.2010.08.046.

72. Chang YC, Yang CY, Sun RL, Cheng YF, Kao WC, Yang PC. Rapid single cell detection of Staphylococcus aureus by aptamer- 
conjugated gold nanoparticles. Sci Rep 2013;3:1-7. https://doi org/10.1038/srep01863.

73. Wu Y, Zhan S, Wang L, Zhou P. Selection of a DNA aptamer for cadmium detection based on cationic polymer mediated aggregation of gold nanoparticles. Analyst 2014;139:1550-61. https://doi.org/10.1039/c3an02117c.

74. Luo Y, Xu J, Li Y, Gao H, Guo J, Shen F, et al. A novel colorimetric aptasensor using cysteamine-stabilized gold nanoparticles as probe for rapid and specific detection of tetracycline in raw milk. Food Control 2015;54:7-15. https://doi.org/10.1016/j. foodcont.2015.01.005.

75. Zhang K, Wang K, Zhu X, Xie M, Xu F. A label-free kissing complexinduced fluorescence sensor for DNA and RNA detection by using DNA-templated silver nanoclusters as a signal transducer. RSC Adv 2016;6:99269-73. https://doi.org/10.1039/C6RA22515B.

76. Andrea E, Robert B. Riboswitches: A Common RNA Regulatory Element. 2010, Nat Educ 3(9)9 n.d.

77. Findeiß S, Etzel M, Will S, Mörl M, Stadler PF. Design of artificial riboswitches as biosensors. Sensors (Switzerland) 2017;17:1-28. https://doi.org/10.3390/s17091990.

78. Barrick JE, Breaker RR. The distributions, mechanisms, and structures of metabolite-binding riboswitches. Genome Biol 2007;8. https://doi.org/10.1186/gb-2007-8-11-r239.

79. Cromie MJ, Shi Y, Latifi T, Groisman EA. An RNA Sensor for Intracellular Mg2+. Cell 2006;125:71-84. https://doi.org/10.1016/j. cell.2006.01.043.

80. Machtel P, Bąkowska-Żywicka K, Żywicki M. Emerging applications of riboswitches - from antibacterial targets to molecular tools. J Appl Genet 2016;57:531-41. https://doi.org/10.1007/s13353-0160341-x.

81. Fowler CC, Brown ED, Li Y. Using a riboswitch sensor to examine coenzyme B12 metabolism and transport in E. coli. Chem Biol 2010;17:756-65. https://doi.org/10.1016/j.chembiol.2010.05.025.

82. Wittung $P$, Nielsen PE, Buchardt $O$, Egholm M, Norde'n B. DNA-like double helix formed by peptide nucleic acid. Nature 1994;368:561-3. https://doi.org/10.1038/368561a0.

83. Briones C, Moreno M. Applications of peptide nucleic acids (PNAs) and locked nucleic acids (LNAs) in biosensor development. Anal Bioanal Chem 2012;402:3071-89. https://doi.org/10.1007/ s00216-012-5742-z.

84. Sharma C, Awasthi SK. Versatility of peptide nucleic acids (PNAs): role in chemical biology, drug discovery, and origins of life. Chem Biol Drug Des 2017;89:16-37. https://doi.org/10.1111/cbdd.12833.

85. Kapoor PKD, Richards SD, Kumar BN. PNA Beacons for Duplex DNA. C Bull Otorhinolaryngol Head Neck Surg 2001;5:71.

86. Lundin KE, Good L, Strömberg R, Gräslund A, Smith CIE. Biological Activity and Biotechnological Aspects of Peptide Nucleic Acid. Adv Genet 2006;56:1-51. https://doi.org/10.1016/ S0065-2660(06)56001-8.

87. D'Agata R, Giuffrida MC, Spoto G. Peptide Nucleic Acid-Based Biosensors for Cancer Diagnosis. Molecules 2017;22:1-15. https:// doi.org/10.3390/molecules22111951.

88. Saadati A, Hassanpour S, Guardia M de la, Mosafer J, Hashemzaei M, Mokhtarzadeh A, et al. Recent advances on application of peptide nucleic acids as a bioreceptor in biosensors development. TrAC - Trends Anal Chem 2019;114:56-68. https:// doi.org/10.1016/j.trac.2019.02.030.

89. Cai B, Wang S, Huang L, Ning Y, Zhang Z, Zhang GJ. Ultrasensitive label-free detection of PNA-DNA hybridization by reduced graphene oxide field-effect transistor biosensor. ACS Nano 2014;8:2632-8. https://doi.org/10.1021/nn4063424.
90. Bora U. Nucleic Acid Based Biosensors for Clinical Applications. Biosens J 2013;02:1-8. https://doi.org/10.4172/20904967.1000104.

91. Varadan VK, Chen L, Xie J. Nanomedicine: Design and Applications of Magnetic Nanomaterials, Nanosensors and Nanosystems. vol. 53. John Wiley \& Sons, 2008; 2012. https:// doi.org/10.1080/00107514.2012.686521.

92. Herne TM, Tarlov MJ. Characterization of DNA Probes Immobilized on Gold Surfaces. J Am Chem Soc 1997;119:8916-20. https://doi.org/10.1021/ja9719586.

93. Bhardwaj T. A Review on Immobilization Techniques of Biosensors. Int J Eng Res Technol 2014;3:294-8.

94. Mo L, Li J, Liu Q, Qiu L, Tan W. Nucleic acid-functionalized transition metal nanosheets for biosensing applications. Biosens Bioelectron 2017;89:201-11. https://doi.org/10.1016/j. bios.2016.03.044.

95. Cui X, Pei R, Wang Z, Yang F, Ma Y, Dong S, et al. Layer-by-layer assembly of multilayer films composed of avidin and biotinlabeled antibody for immunosensing. Biosens Bioelectron 2003;18:59-67. https://doi.org/10.1016/S0956-5663(02)00114-8.

96. Zhu C, Zeng Z, Li H, Li F, Fan C, Zhang H. Single-layer MoS2based nanoprobes for homogeneous detection of biomolecules. J Am Chem Soc 2013;135:5998-6001. https://doi.org/10.1021/ ja4019572.

97. Zhang Y, Zheng B, Zhu C, Zhang X, Tan C, Li H, et al. Single-layer transition metal dichalcogenide nanosheet-based nanosensors for rapid, sensitive, and multiplexed detection of DNA. Adv Mater 2015;27:935-9. https://doi.org/10.1002/adma.201404568.

98. Liu S, Zheng Z, Li X. Advances in pesticide biosensors: Current status, challenges, and future perspectives. Anal Bioanal Chem 2013;405:63-90. https://doi.org/10.1007/s00216-012-6299-6.

99. Wang L, Guo W, Zhu H, He H, Wang S. Preparation and properties of a dual-function cellulose nanofiber-based bionic biosensor for detecting silver ions and acetylcholinesterase. J Hazard Mater 2021;403:123921. https://doi.org/10.1016/j.jhazmat.2020.123921.

100. Jain A, Cheng K. The principles and applications of avidin-based nanoparticles in drug delivery and diagnosis. J Control Release 2017;245:27-40. https://doi.org/10.1016/j.jconrel.2016.11.016.

101. Chung D-J, Kim K-C, Choi S-H. Electrochemical DNA biosensor based on avidin-biotin conjugation for influenza virus (type A) detection. Appl Surf Sci 2011;257:9390-6. https://doi. org/10.1016/j.apsusc.2011.06.015.

102. Terse-Thakoor T, Ramnani P, Villarreal C, Yan D, Tran TT, Pham $T$, et al. Graphene nanogap electrodes in electrical biosensing. Biosens Bioelectron 2019;126:838-44. https://doi.org/10.1016/j. bios. 2018.11.049.

103. Hashkavayi AB, Raoof JB. Nucleic acid-based electrochemical biosensors. Electrochem. Biosens., Elsevier; 2019, p. 253-76. https://doi.org/10.1016/B978-0-12-816491-4.00009-7.

104. Ma C, Zhang M, Chen S, Liang C, Shi C. Rapid and enzyme-free nucleic acid detection based on exponential hairpin assembly in complex biological fluids. Analyst 2016;141:2883-6. https://doi. org/10.1039/c6an00474a.

105. Lu JJ, Ma JQ, Yi JM, Shen ZL, Zhong YJ, Ma CA, et al. Electrochemical polymerization of pyrrole containing TEMPO side chain on pt electrode and its electrochemical activity. Electrochim Acta 2014;130:412-7. https://doi.org/10.1016/j. electacta.2014.03.028.

106. Sinawang PD, Fajs L, Elouarzaki K, Nugraha J, Marks RS. TEMPObased immuno-lateral flow quantitative detection of dengue NS1 protein. Sensors Actuators, B Chem 2018;259:354-63. https:// doi.org/10.1016/j.snb.2017.12.043. 
107. Lin MS, Chen WC, Huang JX, Gao HJ, Sheng HH. Aberrant expression of microRNAs in serum may identify individuals with pancreatic cancer. Int J Clin Exp Med 2014;7:5226-34.

108. Pei Z, Liu S-M, Huang J-T, Zhang X, Yan D, Xia Q, et al. Clinically relevant circulating microRNA profiling studies in pancreatic cancer using meta-analysis. Oncotarget 2017;8:22616-24. https:// doi.org/10.18632/oncotarget.15148.

109. Vincent A, Herman J, Schulick R, Hruban RH, Goggins $M$. Pancreatic cancer. Lancet, vol. 378, 2011, p. 607-20. https://doi. org/10.1016/S0140-6736(10)62307-0.

110. McGuigan A, Kelly P, Turkington RC, Jones C, Coleman HG, McCain RS. Pancreatic cancer: A review of clinical diagnosis, epidemiology, treatment and outcomes. World J Gastroenterol 2018;24:4846-61. https://doi.org/10.3748/wjg.v24.i43.4846.

111. Moutinho-Ribeiro P, Macedo G, Melo SA. Pancreatic cancer diagnosis and management: Has the time come to prick the bubble? Front Endocrinol (Lausanne) 2019;10. https://doi. org/10.3389/fendo.2018.00779.

112. Nielsen P, Egholm M, Berg R, Buchardt O. Sequence-selective recognition of DNA by strand displacement with a thyminesubstituted polyamide. Science (80- ) 1991;254:1497-500. https:// doi.org/10.1126/science.1962210.

113. Cinti S, Moscone D, Arduini F. Preparation of paper-based devices for reagentless electrochemical (bio)sensor strips. Nat Protoc 2019;14:2437-51. https://doi.org/10.1038/s41596-019-0186-y.

114. Li F, Dong Y, Zhang Z, Lv M, Wang Z, Ruan X, et al. A recyclable biointerface based on cross-linked branched DNA nanostructures for ultrasensitive nucleic acid detection. Biosens Bioelectron 2018;117:562-6. https://doi.org/10.1016/j.bios.2018.06.053.

115. John J, Hugar KM, Rivera-Meléndez J, Kostalik HA, Rus ED, Wang $\mathrm{H}$, et al. An Electrochemical Quartz Crystal Microbalance Study of a Prospective Alkaline Anion Exchange Membrane Material for Fuel Cells: Anion Exchange Dynamics and Membrane Swelling. J Am Chem Soc 2014;136:5309-22. https://doi.org/10.1021/ ja4117457.

116. Pei H, Lu N, Wen Y, Song S, Liu Y, Yan H, et al. A DNA nanostructure-based biomolecular probe carrier platform for electrochemical biosensing. Adv Mater 2010;22:4754-8. https:// doi.org/10.1002/adma.201002767.

117. De Luna P, Mahshid SS, Das J, Luan B, Sargent EH, Kelley SO, et al. High-Curvature Nanostructuring Enhances Probe Display for Biomolecular Detection. Nano Lett 2017;17:1289-95. https://doi. org/10.1021/acs.nanolett.6b05153.

118. Sheehan PE, Whitman LJ. Detection limits for nanoscale biosensors. Nano Lett 2005;5:803-7. https://doi.org/10.1021/ nl050298x.

119. Squires TM, Messinger RJ, Manalis SR. Making it stick: Convection, reaction and diffusion in surface-based biosensors. Nat Biotechnol 2008;26:417-26. https://doi.org/10.1038/nbt1388.

120. Tedeschi T, Tonelli A, Sforza S, Corradini R, Marchelli R. A pyrenylPNA probe for DNA and RNA recognition: Fluorescence and UV absorption studies. Artif DNA PNA XNA 2010;1:83-9. https://doi. org/10.4161/adna.1.2.13899.

121. Xu S, Zhang C, Jiang S, Hu G, Li X, Zou Y, et al. Graphene foam field-effect transistor for ultra-sensitive label-free detection of ATP. Sensors Actuators, B Chem 2019;284:125-33. https://doi. org/10.1016/j.snb.2018.12.129.

122. Agashe V, Shenai S, Mohrir G, Deshmukh M, Bhaduri A, Deshpande R, et al. Osteoarticular tuberculosis - Diagnostic solutions in a disease endemic region. J Infect Dev Ctries 2009;3:511-6. https://doi.org/10.3855/jidc.469.
123. Yen P-W, Lu Y-P, Lin C-T, Hwang C-H, Yeh J, Lin M-Y, et al. Emerging Electrical Biosensors for Detecting Pathogens and Antimicrobial Susceptibility Tests. Curr Org Chem 2014;18:165-72. https://doi. org/10.2174/13852728113176660140.

124. Moulin E, Selby K, Cherpillod P, Kaiser L, Boillat-Blanco N. Simultaneous outbreaks of dengue, chikungunya and Zika virus infections: Diagnosis challenge in a returning traveller with nonspecific febrile illness. New Microbes New Infect 2016;11:6-7. https://doi.org/10.1016/j.nmni.2016.02.003.

125. Priyamvada L, Quicke KM, Hudson WH, Onlamoon N, Sewatanon $J$, Edupuganti $S$, et al. Human antibody responses after dengue virus infection are highly cross-reactive to Zika virus. Proc Natl Acad Sci U S A 2016;113:7852-7. https://doi.org/10.1073/ pnas.1607931113.

126. Dejnirattisai W, Supasa P, Wongwiwat W, Rouvinski A, BarbaSpaeth G, Duangchinda T, et al. Dengue virus sero-crossreactivity drives antibody-dependent enhancement of infection with zika virus. Nat Immunol 2016;17:1102-8. https://doi. org/10.1038/ni.3515.

127. Xie B-P, Qiu G-H, Hu P-P, Liang Z, Liang Y-M, Sun B, et al. Simultaneous detection of Dengue and Zika virus RNA sequences with a three-dimensional $\mathrm{Cu}$-based zwitterionic metal-organic framework, comparison of single and synchronous fluorescence analysis. Sensors Actuators B Chem 2018;254:1133-40. https:// doi.org/10.1016/j.snb.2017.06.085.

128. Ye T, Liu Y, Luo M, Xiang X, Ji X, Zhou G, et al. Metal-organic framework-based molecular beacons for multiplexed DNA detection by synchronous fluorescence analysis. Analyst 2014;139:1721-5. https://doi.org/10.1039/c3an02077k.

129. Kumar P, Deep A, Kim KH. Metal organic frameworks for sensing applications. TrAC - Trends Anal Chem 2015;73:39-53. https:// doi.org/10.1016/j.trac.2015.04.009.

130. Zhu X, Zheng H, Wei X, Lin Z, Guo L, Qiu B, et al. Metal-organic framework (MOF): A novel sensing platform for biomolecules. Chem Commun 2013;49:1276-8. https://doi.org/10.1039/ c2cc36661d.

131. Zhang HT, Zhang JW, Huang G, Du ZY, Jiang HL. An aminefunctionalized metal-organic framework as a sensing platform for DNA detection. Chem Commun 2014;50:12069-72. https:// doi.org/10.1039/c4cc05571c.

132. Huo B, Hu Y, Gao Z, Li G. Recent advances on functional nucleic acid-based biosensors for detection of food contaminants. Talanta 2021;222:121565. https://doi.org/10.1016/j.talanta.2020.121565.

133. Vidic J, Vizzini P, Manzano M, Kavanaugh D, Ramarao N, Zivkovic $M$, et al. Point-of-need DNA testing for detection of foodborne pathogenic bacteria. Sensors (Switzerland) 2019;19. https://doi. org/10.3390/s19051100.

134. Yousefi H, Ali MM, Su HM, Filipe CDM, Didar TF. Sentinel Wraps: Real-Time Monitoring of Food Contamination by Printing DNAzyme Probes on Food Packaging. ACS Nano 2018;12:328794. https://doi.org/10.1021/acsnano.7b08010.

135. Li S, Liu S, Xu Y, Zhang R, Zhao Y, Qu X, et al. Robust and highly specific fluorescence sensing of: Salmonella typhimurium based on dual-functional phi29 DNA polymerase-mediated isothermal circular strand displacement polymerization. Analyst 2019;144:4795-802. https://doi.org/10.1039/c9an00843h.

136. Eurosurveillance editorial team. The European Union summary report on trends and sources of zoonoses, zoonotic agents and food-borne outbreaks in 2010. Euro Surveill 2012;17. https://doi. org/10.2903/j.efsa.2012.2597.

137. Shen H, Wang J, Liu H, Li Z, Jiang F, Wang FB, et al. Rapid and Selective Detection of Pathogenic Bacteria in Bloodstream Infections with Aptamer-Based Recognition. ACS Appl 
Mater Interfaces 2016;8:19371-8. https://doi.org/10.1021/ acsami.6b06671.

138. Chen Z, Liu Y, Xin C, Zhao J, Liu S. A cascade autocatalytic strand displacement amplification and hybridization chain reaction event for label-free and ultrasensitive electrochemical nucleic acid biosensing. Biosens Bioelectron 2018;113:1-8. https://doi. org/10.1016/j.bios.2018.04.046.

139. Endo MS, Signoretti FGC, Kitayama VS, Marinho ACS, Martinho FC, Gomes BPFDA. Investigation in vivo of enterococcus faecalis in endodontic retreatment by phenotypic and genotypic methods. Acta Sci - Heal Sci 2015;37:95-103. https://doi. org/10.4025/actascihealthsci.v37i1.24348.

140. Kim HS, Hahn H, Kim J, Jang DM, Lee JY, Back JM, et al. Structural basis for the substrate recognition of peptidoglycan pentapeptides by Enterococcus faecalis VanYB. Int J Biol Macromol 2018;119:335-44. https://doi.org/10.1016/j.ijbiomac.2018.07.081.

141. de Lucena JMVM, Decker EM, Walter C, Boeira LS, Löst C, Weiger R. Antimicrobial effectiveness of intracanal medicaments on Enterococcus faecalis : chlorhexidine versus octenidine. Int Endod J 2013;46:53-61. https://doi.org/10.1111/j.13652591.2012.02093.x.

142. Oesterle ME, Wright K, Fidler M, Johnson P, Bialonska D. Are ball pits located in physical therapy clinical settings a source of pathogenic microorganisms? Am J Infect Control 2019;47:456-8. https://doi.org/10.1016/j.ajic.2018.09.031.

143. Giraffa G. Enterococci from foods. FEMS Microbiol Rev 2002;26:163-71. https://doi.org/10.1111/j.1574-6976.2002. tb00608.x.

144. Andrighetto C, Knijff E, Lombardi A, Torriani S, Vancanneyt M, Kersters K, et al. Phenotypic and genetic diversity of enterococci isolated from Italian cheeses. J Dairy Res 2001;68:303-16. https:// doi.org/10.1017/S0022029901004800.

145. Oprea SF, Zervos MJ. Enterococcus and its Association with Foodborne Illness. Foodborne Dis., 2007, p. 157-74. https://doi. org/10.1007/978-1-59745-501-5_6.

146. Abkar M, Alamian S, Sattarahmady N. A comparison between adjuvant and delivering functions of calcium phosphate, aluminum hydroxide and chitosan nanoparticles, using a mode protein of Brucella melitensis Omp31. Immunol Lett 2019;207:2835. https://doi.org/10.1016/j.imlet.2019.01.010.

147. Gorgizadeh M, Azarpira N, Sattarahmady N. In vitro and in vivo tumor annihilation by near-infrared photothermal effect of a NiFe2O4/C nanocomposite. Colloids Surfaces B Biointerfaces 2018;170:393-400. https://doi.org/10.1016/j. colsurfb.2018.06.034.

148. Gorgizadeh M, Azarpira N, Dehdari Veis R, Sattarahmady $\mathrm{N}$. Repression of melanoma tumor in vitro and in vivo by photothermal effect of carbon xerogel nanoparticles. Colloids Surfaces B Biointerfaces 2019;176:449-55. https://doi. org/10.1016/j.colsurfb.2019.01.032.

149. Negahdary M, Behjati-Ardakani M, Sattarahmady N, Heli H. An aptamer-based biosensor for troponin i detection in diagnosis of myocardial infarction. J Biomed Phys Eng 2018;8:167-78. https:// doi.org/10.22086/jbpe.v0i0.930.

150. Sattarahmady N, Rezaie-Yazdi M, Tondro GH, Akbari N. Bactericidal laser ablation of carbon dots: An in vitro study on wild-type and antibiotic-resistant Staphylococcus aureus. J Photochem Photobiol B Biol 2017;166:323-32. https://doi. org/10.1016/j.jphotobiol.2016.12.006.

151. Sattarahmady N, Firoozabadi V, Nazari-Vanani R, Azarpira N. Investigation of amyloid formation inhibition of chemically and biogenically from Citrus aurantium L. blossoms and Rose damascena oils of gold nanoparticles: Toxicity evaluation in rat pheochromocytoma PC12 cells. Int J Biol Macromol 2018;112:70311. https://doi.org/10.1016/j.ijbiomac.2018.02.025.

152. Nazari-Vanani R, Sattarahmady N, Yadegari H, Khatami M, Heli $\mathrm{H}$. Electrochemical biosensing of 16s rRNA gene sequence of Enterococcus faecalis. Biosens Bioelectron 2019;142:111541. https://doi.org/10.1016/j.bios.2019.111541.

153. Heli H. A study of double stranded DNA adsorption on aluminum surface by means of electrochemical impedance spectroscopy. Colloids Surfaces B Biointerfaces 2014;116:526-30. https://doi. org/10.1016/j.colsurfb.2014.01.046.

154. Whitesides GM, Grzybowski B. Self-assembly at all scales. Science (80- ) 2002;295:2418-21. https://doi.org/10.1126/science.1070821.

155. Martelet C, Jaffrezic-Renault N, Hou Y, Errachid A, Bessueille F. Nanostructuration and Nanoimaging of Biomolecules for Biosensors, Springer, Berlin, Heidelberg ; 2007, p. 225-57. https://doi.org/10.1007/978-3-540-37321-6_6.

156. Hasan A, Pandey LM. Self-assembled monolayers in biomaterials. Nanobiomaterials, Elsevier; 2018, p. 137-78. https://doi. org/10.1016/B978-0-08-100716-7.00007-6.

157. Ma F, Lennox RB. Potential-assisted deposition of alkanethiols on Au: Controlled preparation of single- and mixed-component SAMs. Langmuir 2000;16:6188-90. https://doi.org/10.1021/ la9913046.

158. Fozooni T, Ravan H, Sasan H. Signal Amplification Technologies for the Detection of Nucleic Acids: from Cell-Free Analysis to Live-Cell Imaging. Appl Biochem Biotechnol 2017;183:1224-53. https://doi.org/10.1007/s12010-017-2494-4.

159. Fakruddin M, Mannan K Bin, Hossain M, Islam S, Mazumdar R, Chowdhury A, et al. Nucleic acid amplification: Alternative methods of polymerase chain reaction. J Pharm Bioallied Sci 2013;5:245. https://doi.org/10.4103/0975-7406.120066.

160. Zanoli L, Spoto G. Isothermal Amplification Methods for the Detection of Nucleic Acids in Microfluidic Devices. Biosensors 2012;3:18-43. https://doi.org/10.3390/bios3010018.

161. Yuan R, Ding S, Yan Y, Zhang Y, Zhang Y, Cheng W. A facile and pragmatic electrochemical biosensing strategy for ultrasensitive detection of DNA in real sample based on defective $T$ junction induced transcription amplification. Biosens Bioelectron 2016;77:19-25. https://doi.org/10.1016/j.bios.2015.09.009.

162. Yan Y, Ding S, Zhao D, Yuan R, Zhang Y, Cheng W. Direct ultrasensitive electrochemical biosensing of pathogenic DNA using homogeneous target-initiated transcription amplification. Sci Rep 2016;6:18810. https://doi.org/10.1038/srep18810.

163. Tu Y, Ho Y, Chuang Y, Chen P, Chen C. Identification of Lactoferricin B Intracellular Targets Using an Escherichia coli Proteome Chip 2011;6. https://doi.org/10.1371/journal.pone.0028197.

164. Saha K, Agasti SS, Kim C, Li X, Rotello VM. Gold nanoparticles in chemical and biological sensing. Chem Rev 2012;112:2739-79. https://doi.org/10.1021/cr2001178.

165. Mao $Y$, Bao $Y$, Han Dx, Zhao B. Research Progress on Nitrite Electrochemical Sensor. Chinese J Anal Chem 2018;46:147-55. https://doi.org/10.1016/S1872-2040(17)61066-1.

166. Zhu Y, Zeng G, Zhang Y, Tang L, Chen J, Cheng M, et al. Highly sensitive electrochemical sensor using a MWCNTs/GNPsmodified electrode for lead (II) detection based on $\mathrm{Pb} 2+$-induced G-rich DNA conformation. Analyst 2014;139:5014. https://doi. org/10.1039/C4AN00874J.

167. Chen J, Huang Z, Luo Z, Yu Q, Xu Y, Wang X, et al. MultichannelStructured Three-Dimensional Chip for Highly Sensitive Pathogenic Bacteria Detection Based on Fast DNA-Programmed Signal Polymerization. Anal Chem 2018;90:12019-26. https://doi. org/10.1021/acs.analchem.8b02650. 
168. Wu P, Li S, Ye X, Ning B, Bai J, Peng Y, et al. Cu/Au/Pt trimetallic nanoparticles coated with DNA hydrogel as target-responsive and signal-amplification material for sensitive detection of microcystin-LR. Anal Chim Acta 2020;1134:96-105. https://doi. org/10.1016/j.aca.2020.08.004.

169. Liu Y, Ji J, Cui F, Sun J, Wu H, Pi F, et al. Development of a twostep immunochromatographic assay for microcystin-LR based on fluorescent microspheres. Food Control 2019;95:34-40. https:// doi.org/10.1016/j.foodcont.2018.07.036.

170. Zhang W, Han C, Jia B, Saint C, Nadagouda M, Falaras P, et al. A 3D graphene-based biosensor as an early microcystin-LR screening tool in sources of drinking water supply. Electrochim Acta 2017;236:319-27. https://doi.org/10.1016/j.electacta.2017.03.161.

171. Arora P, Sindhu A, Dilbaghi N, Chaudhury A. Biosensors as innovative tools for the detection of food borne pathogens. Biosens Bioelectron 2011;28:1-12. https://doi.org/10.1016/j. bios.2011.06.002.

172. Ercole C, Del Gallo M, Mosiello L, Baccella S, Lepidi A. Escherichia coli detection in vegetable food by a potentiometric biosensor. Sensors Actuators, B Chem 2003;91:163-8. https://doi. org/10.1016/S0925-4005(03)00083-2.

173. Torun Ö, Hakki Boyaci I, Temür E, Tamer U. Comparison of sensing strategies in SPR biosensor for rapid and sensitive enumeration of bacteria. Biosens Bioelectron 2012;37:53-60. https://doi. org/10.1016/j.bios.2012.04.034.

174. Yan C, Dong F, Chun-yuan B, Si-rong Z, Jian-guo S. Recent Progress of Commercially Available Biosensors in China and Their Applications in Fermentation Processes. J Northeast Agric Univ (English Ed 2014;21:73-85. https://doi.org/10.1016/s10068104(15)30023-4.

175. Chen QH, Yang Y, He HL, Xie JF, Cai SX, Liu AR, et al. The effect of glutamine therapy on outcomes in critically ill patients: A meta- analysis of randomized controlled trials. Crit Care 2014;18:R8. https://doi.org/10.1186/cc13185.

176. Bäcker M, Rakowski D, Poghossian A, Biselli M, Wagner P, Schöning MJ. Chip-based amperometric enzyme sensor system for monitoring of bioprocesses by flow-injection analysis. J Biotechnol 2013;163:371-6. https://doi.org/10.1016/j. jbiotec.2012.03.014.

177. Ghasemi-Varnamkhasti M, Rodríguez-Méndez ML, Mohtasebi SS, Apetrei C, Lozano J, Ahmadi H, et al. Monitoring the aging of beers using a bioelectronic tongue. Food Control 2012;25:21624. https://doi.org/10.1016/j.foodcont.2011.10.020.

178. Mishra RK, Dominguez RB, Bhand S, Muñoz R, Marty JL. A novel automated flow-based biosensor for the determination of organophosphate pesticides in milk. Biosens Bioelectron 2012;32:56-61. https://doi.org/10.1016/j.bios.2011.11.028.

179. Arduini F, Ricci F, Tuta CS, Moscone D, Amine A, Palleschi G. Detection of carbamic and organophosphorous pesticides in water samples using a cholinesterase biosensor based on Prussian Blue-modified screen-printed electrode. Anal Chim Acta 2006;580:155-62. https://doi.org/10.1016/j.aca.2006.07.052.

180. Suprun E, Evtugyn G, Budnikov H, Ricci F, Moscone D, Palleschi $\mathrm{G}$. Acetylcholinesterase sensor based on screen-printed carbon electrode modified with prussian blue. Anal Bioanal Chem 2005;383:597-604. https://doi.org/10.1007/s00216-005-0002-0.

181. Ivanov A, Evtugyn G, Budnikov H, Ricci F, Moscone D, Palleschi G. Cholinesterase sensors based on screen-printed electrodes for detection of organophosphorus and carbamic pesticides. Anal Bioanal Chem 2003;377:624-31. https://doi.org/10.1007/ s00216-003-2174-9. 